\title{
CONSTRUCTED WETLANDS FOR WATER QUALITY IMPROVEMENT: A SYNTHESIS ON NUTRIENT REDUCTION FROM AGRICULTURAL EFFLUENTS
}

\author{
T. L. Messer, T. L. Moore, N. Nelson, L. Ahiablame, E. Z. Bean, \\ C. Boles, S. L. Cook, S. G. Hall, J. McMaine, D. Schlea
}

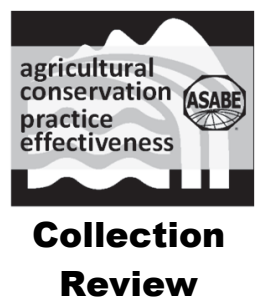

\begin{abstract}
Excess nutrients from agricultural settings contribute to surface water and groundwater impairment. Constructed wetlands have been widely used for water quality protection in various agricultural systems. We used a synthesis approach to document the performance of constructed wetlands for nutrient removal from a range of landscapes and geographic regions with the following objectives: (1) review the current use of constructed wetlands in agricultural applications, (2) summarize the nutrient removal efficiency of constructed wetlands, and (3) identify the geographic usage and costs associated with constructed wetlands. We reviewed over 130 publications and reports to characterize nutrient removal performance for the following types of agricultural effluents: cropland surface and subsurface drainage, and wastewater from livestock production, greenhouse, aquaculture, and hydroponic systems. Data from the reviewed studies indicate that constructed wetlands are efficient in protecting water quality in agricultural production settings. However, differences in constructed wetland characteristics reported by the studies suggest that standards are needed to ensure nutrient removal goals are met based on wetland design. Researchers should consider including basic performance parameters for constructed wetlands in published reports, including influent and effluent concentrations, hydraulic retention time, hydraulic loading rate, watershed to treatment wetland ratios, and plant species and relative cover. Future studies are needed to explore cost-benefit analyses to assess the feasibility and potential promotion of wetland incentive programs in various geographic regions and watershed nonpoint-source pollution goals for using these systems in agricultural settings.
\end{abstract}

Keywords. Agricultural wastewater, Agricultural water quality, Aquaculture, Cropland runoff, Greenhouse, Hydroponic, Livestock, Review, Subsurface, Treatment wetland.

Submitted for review on 24 February 2020 as manuscript number NRES 13976; approved for publication as an Invited Review Article and as part of the Agricultural Conservation Practice Effectiveness Collection by the Natural Resources \& Environmental Systems Community of ASABE on 6 December 2020.

The authors are Tiffany L. Messer, Assistant Professor, Department of Biosystems and Agricultural Engineering, University of Kentucky, Lexington, Kentucky; Trisha L. Moore, Assistant Professor, Department of Biological and Agricultural Engineering, Kansas State University, Manhattan, Kansas; Natalie Nelson, Assistant Professor, Department of Biological and Agricultural Engineering, North Carolina State University, Raleigh, North Carolina; Laurent Ahiablame, Director of Agricultural and Natural Resources Division and Water Management Advisor, University of California, San Diego, California; Eban Z. Bean, Assistant Professor, Department of Agricultural and Biological Engineering, University of Florida, Gainesville, Florida; Chelsie Boles, Project Engineer, LimnoTech, Ann Arbor, Michigan; Sonja L. Cook, Staff Engineer, Plummer Associates, Inc., Fort Worth, Texas; Steven G. Hall, Associate Professor and Director of Marine Aquaculture Research Center, Department of Biological and Agricultural Engineering, North Carolina State University, Raleigh, North Carolina; John McMaine, Assistant Professor, Department of Agricultural and Biosystems Engineering, South Dakota State University, Brookings, South Dakota; Derek Schlea, Project Engineer, LimnoTech, Ann Arbor, Michigan. Corresponding author: Tiffany Messer, 128 CE Barnhart, Lexington, KY 40506; phone: 859-218-4353; email: tiffany.messer@uky.edu.

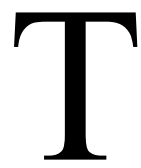
his article is part of a collection that provides a comprehensive review and evaluation of the performance and cost-effectiveness of selected agricultural conservation practices (ACPs) for sediment and nutrient reduction. Defined as "an artificial wetland ecosystem with hydrophytic vegetation for biological treatment of water" (NRCS, 2013), a constructed wetland (NRCS Code 656) is an ACP largely used for water quality improvement. Constructed wetlands (also called constructed treatment wetlands) are engineered systems that replicate the functions of vegetation, soils, and associated microbial activities of natural wetlands to improve water quality (USEPA, 2004). In contrast, natural wetlands are distinct land areas that are inundated or saturated by surface or groundwater, either permanently or seasonally, at a frequency and duration sufficient to support vegetation typically adapted to grow in saturated soil conditions.

Important ecological functions of wetlands include, among others, water purification, flood protection, shoreline stabilization, groundwater recharge, streamflow maintenance, and biodiversity protection (Acreman and Holden, 2013; Mitsch and Gossilink, 2000; Zedler and Kercher, 2005). Wetlands provide natural pollution control by retaining nutrients and sediment from runoff to prevent downstream eutrophication, flood control by slowing water as it 
flows through the system and storing excess water during storm events, shoreline stabilization by promoting deposition of sediment carried in the water that would otherwise create streambank erosion and clog downstream lakes and reservoirs, and groundwater recharge and streamflow maintenance by allowing water to percolate into the ground or evaporate (Dahl, 2000; Zedler, 2003; Zedler and Kercher, 2005). Numerous species of plants and animals, including endangered species, rely on wetlands for food, water, and shelter (Dahl, 2000; Zedler, 2003). Scientists have also credited wetlands with atmospheric maintenance as wetlands store carbon through peat storage instead of releasing it to the atmosphere as carbon dioxide, thus mitigating the effects of climate change (Eulis et al., 2006; Zedler and Kercher, 2005). The Interagency Workgroup, comprised of the U.S. Environmental Protection Agency (USEPA), U.S. Army Core of Engineers (USACE), U.S. Fish and Wildlife Service (FWS), USDA Natural Resources Conservation Service (NRCS), National Marine Fisheries Service (NRFS), and the U.S. Bureau of Reclamation (USBR), developed a roadmap for the siting, design, construction, and maintenance of constructed wetlands for the U.S. (Hayes et al., 2000; USEPA, 2000; USACE, 1987). In summary, the roadmap includes guidance for the suitability of a site to construct a wetland and its role within the watershed (siting), placement of the structure as a natural transition zone with vector control mechanisms (design), permeability of soil and selection of vegetation to use (construction), and proper management plans with regular inspections and maintenance activities (operation and maintenance) (USEPA, 2000).

Constructed wetlands have been used in various agricultural systems, including subsurface and surface drainage, greenhouses, livestock manure management, aquaculture, and hydroponics wastewater systems (e.g., Hammer, 1989; Kovacic et al., 2006; Moshiri, 1993; Peterson, 1998; Vymazal, 2007). The increasing use of constructed wetlands in recent years for municipal wastewater treatment and agricultural water quality improvement has been facilitated by advancement in research and technology within these systems (Castelle et al., 1994; Hammer, 1989; Zedler, 2003). While the environmental benefits of wetlands (i.e., wetland functions and values) have been widely acknowledged (Dahl, 2000; Zedler, 2003; Zedler and Kercher, 2005), there is a need to assess wetland design characteristics and performance parameters. Such efforts would enhance the current USDA-NRCS wetland standard for treating agricultural effluents.

Here, we provide a quantitative synthesis of the present literature to document the use, performance, and costs of constructed wetlands in agricultural landscapes for nutrient reduction. We focused on wetlands treating agricultural effluents, which differ substantially from municipal wastewater and runoff in terms of the variability in hydraulic loading rates and associated constituent characteristics (e.g., nutrients, $\mathrm{pH}$, dissolved organic carbon; Loehr, 1972; Novotny, 1999). We also reviewed current design measures for wetlands treating a variety of agricultural effluents as a step for developing agriculture-focused constructed wetland standards. The specific objectives of this synthesis article are to: (1) review the current use of constructed wetlands in agricultural applications, (2) summarize the nutrient removal efficiency of constructed wetlands, and (3) identify their geographic usage and the costs associated with constructed wetlands.

\section{METHOD}

In this synthesis article, we reviewed the global literature with a focus on the performance of constructed wetlands in agricultural systems and their design characteristics. Keywords common to constructed wetlands, potential agricultural source waters, nitrogen $(\mathrm{N})$ species, and phosphorus $(\mathrm{P})$ species were used to search scholarly databases such as Google Scholar and Web of Science and compile potentially relevant peer-reviewed articles, technical reports, books, conference proceedings, design guidelines, and fact sheets. Documents resulting from this search were screened to include only full-scale applications of constructed wetlands for nutrient ( $\mathrm{N}$ and $\mathrm{P}$ ) management; we did not consider results of bench-scale or mesocosm experiments or watershed assessments and/or modeling studies. This search and screening process resulted in 71 publications, which were then directly or indirectly summarized in this article. We assembled a database of wetland design and nutrient treatment parameters of the peer-reviewed articles in the supplemental material (https://doi.org/10.6084/m9.figshare.13664714.v1). We organized the review in sections to highlight constructed wetland usage in various agricultural systems identified through the literature review process, respective wetland performance, economic costs, and recommendations for future research and potential updates to the standard. Nutrient removal performance was characterized in the following sections for each of the following types of agricultural influent entering constructed wetlands: cropland runoff, cropland subsurface drainage water, wastewater from livestock production, greenhouse effluent, aquaculture effluent, and hydroponic effluent. The sections were developed in this way due to the large variability between effluents entering wetlands and their distinctly different water chemistries and hydraulic loading characteristics. For example, wastewater from livestock production typically had significantly higher total $\mathrm{P}$ concentrations compared to other influents (Bayo et al., 2012). In contrast, $\mathrm{NO}_{3}-\mathrm{N}$ concentrations were significantly higher in hydroponic systems compared to the other influents (Narváez et al., 2011).

Nutrient concentrations were reported and analyzed for this study, given the limited reporting of nutrient loads in many of the agricultural constructed wetland studies. Ideally both would be reported, given that nutrient concentrations are useful for assessing water quality from an ecotoxicity and human health perspective, while nutrient loading is helpful for understanding contributions to meeting federal total maximum daily load (TMDL) goals within a watershed. However, specifically in wetlands receiving influent water from cropland runoff, calculating a load is often challenging due to the complexity in estimating runoff volume entering constructed wetlands following a given precipitation event. A limitation of only assessing nutrient concentrations in this review was that the impacts of dilution and evapotranspiration 
on concentrations were not considered due to limited studies using conservative tracers (e.g., bromide, chloride).

A similar literature search was performed to identify studies presenting life cycle economic costs (e.g., design and construction, operation and maintenance) relative to reported $\mathrm{N}$ and/or $\mathrm{P}$ reduction performance for constructed wetlands treating agricultural effluent sources. This review was limited to economic costs and did not consider the value of other wetland benefits. A total of seven studies was identified through this search. To address the range in time across which economic data were reported, all reported capital and recurring costs were converted to 2019 dollars using the Consumer Price Index reported by the U.S. Bureau of Labor Statistics (BLS, 2019). Likewise, because individual studies used different time horizons and discount rates over which to annualize costs, a common time of 15 years (consistent with NRCS expected life for constructed wetland design) and a discount rate of 3.4\% (consistent with 2019 USDA rates; USDA-NRCS, 2019) were applied to reported operating and maintenance costs in each study to obtain comparable annualized life cycle costs.

\section{Statistical Assessment}

All wetland data were tested for normality and outliers. Outliers were removed, and datasets were normalized by log transformation, if required. Influent and effluent nutrient concentrations (total $\mathrm{N}$, nitrate- $\mathrm{N}$, ammonium- $\mathrm{N}$, total $\mathrm{P}$, and dissolved inorganic P), hydraulic retention time (HRT), hydraulic loading rate (HLR), wetland area, and percentage nutrient removals were assessed using ANOVA. Relationships between wetland effluent nutrient concentrations to wetland nutrient influent concentrations, HRT, HLR, and wetland area were tested using linear regression. Factors impacting predictions (e.g., effluent concentrations and percentage removal of individual nutrients) were determined using $\mathrm{p}$-values and adjusted $\mathrm{R}^{2}$. Reported significance was determined at $\alpha=0.05$. All statistical analyses were completed in Minitab 17 (Minitab, 2010).

\section{Performance EfFectiveness NUTRIENT TRANSFORMATION PROCESSES IN CONSTRUCTED WeTLANDS}

Nutrient transformations and fate in constructed wetlands designed to receive agricultural influent water with a significant nutrient load must be understood to protect downstream water and maximize removal and wetland treatment efficiency. Nitrogen cycling in wetlands involves complex physical and microbial processes. Primary $\mathrm{N}$ transformation processes include nitrification, denitrification, plant uptake, microbial assimilation, and mineralization (Walbridge and Lockaby, 1994). Secondary processes include sediment immobilization, dissimilatory nitrate reduction to ammonium (DNRA), anaerobic ammonium oxidation (Anammox), and volatilization. Nitrification, the biological oxidation of ammonium-N performed by autotrophic bacteria, occurs when ammonium-N $\left(\mathrm{NH}_{4}-\mathrm{N}\right)$ is converted to nitrate- $\mathrm{N}$ in aerobic conditions. In contrast, denitrification is the microbial process though which nitrate- $\mathrm{N}\left(\mathrm{NO}_{3}-\mathrm{N}\right)$ is reduced and transformed into nitrogen gas $\left(\mathrm{N}_{2}\right)$ by facultative anaerobic bacteria in anaerobic conditions. Biogeochemical processes, such as nitrification and denitrification, in constructed wetland environments are dependent on a variety of factors (e.g., oxygen availability, carbon quality and availability, soil and water $\mathrm{pH}$, and soil and water temperature; Burchell et al., 2007; Hefting et al., 2005; Knowles, 1982; Rust et al., 2000). Additionally, these conditions change quickly depending on water level, light, season, and the occurrence of extreme events (Jager et al., 2009; Jørgensen and Elberling, 2012; Liu et al., 2010; Mustafa and Scholz, 2011). In comparison, plant uptake is often considered a temporary removal, as $\mathrm{N}$ is absorbed into the plant to later be released in organic forms at the end of the growing season (Messer et al., 2017b). However, hydrophytic plants are critical for creating appropriate biogeochemical settings for nutrients and emerging contaminant removal from the water column (Mercado-Borrayo et al., 2015; Moore et al., 2007). Further, plant uptake of nutrients is species and environmentally specific, often creating challenges for comparing nutrient removal rates between varying constructed wetland treatment designs. Unlike $\mathrm{N}$, there is no permanent removal pathway for $\mathrm{P}$ delivered to constructed wetlands; rather, it is cycled among various $\mathrm{P}$ pools via plant uptake, microbial assimilation, and sedimentation. Particle-bound inorganic phosphate-P $\left(\mathrm{PO}_{4}-\mathrm{P}\right)$ is removed from wetlands through sedimentation, the process of sediment settling in a system, or plant uptake. Specifically, $\mathrm{PO}_{4}-\mathrm{P}$ will bind to sediments in oxic conditions and settle in the sediment of the constructed wetland ( $\mathrm{Lu}$ et al., 2009). However, in the event anoxic conditions occur, $\mathrm{PO}_{4}-\mathrm{P}$ is often released from the sediments and regenerated back into the water column (Pant and Reddy, 2003).

\section{CONSTRUCTED WetLANDS FOR CROPLAND}

Constructed wetlands have been used to improve water quality delivered from cropland via two predominant pathways: surface flows (e.g., precipitation-driven runoff or irrigation tailwaters) or subsurface drainage (e.g., tile drainage). Table 1 summarizes the data compiled from 39 scholarly papers (28 surface-flow influent sources and 11 subsurface drainage influent sources), representing studies conducted on three continents (North America, Europe, Asia) and published between the years 2000 and 2019 (Bass, 2000; Beutel et al., 2014; Blankenberg et al., 2016; Borin and Tocchetto, 2007; Braskerud, 2002; Chen et al., 2015; Díaz et al., 2012; Dunne et al., 2015; Fink and Mitsch, 2004; Goddard and Elder, 1997; Gu, 2008; Han et al., 2017; Haverstock et al., 2017; Hoagland et al., 2001; Hoffmann et al., 2012; Juston and DeBusk, 2006; Kasak et al., 2018; Kim et al., 2010; Koskiaho et al., 2003; Kovacic et al., 2000, 2006; Larson et al., 2000; Lavrnić et al., 2018; Lentz et al., 2014; Liikanen et al., 2004; Lu et al., 2009; Ludwig, 2010; Maniquiz et al., 2012; Maxwell et al., 2017; Miller et al., 2002; MorenoMateos et al., 2009; Mustafa et al., 2009; Pietro and Ivanoff, 2015; Poe et al., 2003; Reinhardt et al., 2005; Sim et al., 2008; Søvik and Mørkved, 2008; Thoren et al., 2004; Tolomio et al., 2019; Tonderski et al., 2005). A complete table of the nutrient reduction performance and design components for each of these studies can be found in the supplemental material. Constructed wetlands in these studies 
Table 1. Mean influent and effluent nitrogen $\left(\mathrm{TN}=\right.$ total nitrogen, $\mathrm{NO}_{3}-\mathrm{N}=$ nitrate-N, and $\mathrm{NH}_{4}-\mathrm{N}=$ ammonium-N) and phosphorus $(\mathrm{TP}=$ total phosphorus, and DIP = dissolved inorganic phosphate) concentrations $\left(\mathrm{mg} \mathrm{L}^{-1}\right)$ and percentage removals reported for constructed wetlands treating surface runoff or subsurface drainage from agricultural cropland (minimum/maximum values shown in parentheses).

\begin{tabular}{|c|c|c|c|c|c|c|}
\hline Nutrient Source & & $\mathrm{TN}$ & $\mathrm{NO}_{3}-\mathrm{N}$ & $\mathrm{NH}_{4}-\mathrm{N}$ & TP & DIP \\
\hline \multirow{3}{*}{$\begin{array}{l}\text { Surface runoff } \\
(n=28 \text { studies })\end{array}$} & Influent $\left(\mathrm{mg} \mathrm{L}^{-1}\right)$ & $\begin{array}{c}6.4 \\
(0.8 / 16.2) \\
\end{array}$ & $\begin{array}{c}4.4 \\
(0.28 / 18.5)\end{array}$ & $\begin{array}{c}0.7 \\
(0.05 / 3.6)\end{array}$ & $\begin{array}{c}0.3 \\
(0.03 / 5.4)\end{array}$ & $\begin{array}{c}0.1 \\
(0.005 / 0.3)\end{array}$ \\
\hline & Effluent $\left(\mathrm{mg} \mathrm{L}^{-1}\right)$ & $\begin{array}{c}4.8 \\
(0.07 / 9.77) \\
\end{array}$ & $\begin{array}{c}2.6 \\
(0.001 / 9) \\
\end{array}$ & $\begin{array}{c}0.3 \\
(0.04 / 1.2) \\
\end{array}$ & $\begin{array}{c}0.2 \\
(0.01 / 4.3) \\
\end{array}$ & $\begin{array}{c}0.1 \\
(0 / 0.4) \\
\end{array}$ \\
\hline & Removal (\%) & $\begin{array}{c}13.9 \\
(-127 / 96.7)\end{array}$ & $\begin{array}{c}45.3 \\
(10.8 / 99.6)\end{array}$ & $\begin{array}{c}20.0 \\
(-120 / 65.9)\end{array}$ & $\begin{array}{c}35.3 \\
(-109 / 89)\end{array}$ & $\begin{array}{c}24.2 \\
(-138 / 100)\end{array}$ \\
\hline \multirow{3}{*}{$\begin{array}{l}\text { Subsurface drainage } \\
\quad(n=11 \text { studies })\end{array}$} & Influent $\left(\mathrm{mg} \mathrm{L}^{-1}\right)$ & $\begin{array}{c}11.0 \\
(2.0 / 19.9)\end{array}$ & $\begin{array}{c}10.5 \\
(1.5 / 19.8) \\
\end{array}$ & $\begin{array}{c}0.43 \\
(0 / 2.6)\end{array}$ & $\begin{array}{c}0.2 \\
(0.01 / 0.5)\end{array}$ & $\begin{array}{c}0.1 \\
(0.01 / 0.3)\end{array}$ \\
\hline & Effluent $\left(\mathrm{mg} \mathrm{L}^{-1}\right)$ & $\begin{array}{c}8.6 \\
(0.5 / 14.8) \\
\end{array}$ & $\begin{array}{c}7.4 \\
(0.1 / 14.4)\end{array}$ & $\begin{array}{c}0.39 \\
(0 / 2.3)\end{array}$ & $\begin{array}{c}0.2 \\
(0.02 / 0.4)\end{array}$ & $\begin{array}{c}0.1 \\
(0.02 / 0.3)\end{array}$ \\
\hline & Removal (\%) & $\begin{array}{c}23.7 \\
(-20 / 76.7)\end{array}$ & $\begin{array}{c}30.3 \\
(-29 / 92.2)\end{array}$ & $\begin{array}{c}-77.2 \\
(-400 / 46.2)\end{array}$ & $\begin{array}{c}-30.5 \\
(-256 / 66.7)\end{array}$ & $\begin{array}{c}-19.3 \\
(-291 / 77.8)\end{array}$ \\
\hline
\end{tabular}

ranged in size from $<1$ ha to 6,700 ha with contributing watershed areas ranging from $<1 \mathrm{~km}^{2}$ to $>2,500 \mathrm{~km}^{2}$. The mean ratio between the wetland treatment area and its contributing drainage area (referred to hereafter as the treatment area ratio) was $2.6 \%$ (range $0.003 \%$ to $7.5 \%$ ) for constructed wetlands treating surface runoff and $4.8 \%$ (range $0.1 \%$ to $15 \%$ ) for constructed wetlands treating subsurface drainage. Average HRTs and HLRs were also extracted from these studies when reported. Reported HRTs tended to be longer in wetlands designed to treat subsurface drainage (mean 13 days; range 5 to 35 days) relative to wetlands treating surface runoff (mean 4.7 days; range 1.7 hours to 17 days). Likewise, reported HLRs tended to be higher for wetlands treating surface flows (mean $17.9 \mathrm{~cm} \mathrm{~d}^{-1}$; range 1.7 to $450 \mathrm{~cm} \mathrm{~d}^{-1}$ ) compared to wetlands designed for subsurface drainage (mean $3.4 \mathrm{~cm} \mathrm{~d}^{-1}$; range 0.4 to $9 \mathrm{~cm} \mathrm{~d}^{-1}$ ).

The influent and effluent nutrient concentrations and associated percentage reductions (on a concentration basis) extracted from this collection of studies are summarized in table 1. Although concentrations and associated removal efficiencies varied widely within and among studies, this dataset suggests that constructed wetlands reduce $\mathrm{N}$ and $\mathrm{P}$ concentrations from cropland-dominated watersheds, with mean reduction efficiencies ranging from $13.9 \%$ to $45 \%$ (table 1 ). Mean treatment efficiencies for $\mathrm{NH}_{4}-\mathrm{N}, \mathrm{TP}$, and DIP by wetlands treating subsurface drainage waters were negative, indicating increases in concentrations. However, these negative percentage reductions in this dataset were associated with low influent concentrations (table 1). In the case of TP and DIP, both influent and effluent $\mathrm{P}$ concentrations approached irreducible concentrations for P removal (Kadlec and Knight, 1996), indicating that these wetlands were still performing in line with expectations. Increases in $\mathrm{NH}_{4}-\mathrm{N}$ through these wetlands were likely driven by internal processing and transformations of other influent $\mathrm{N}$ forms. For example, DNRA has been shown to be a dominant nitrate transformation pathway under certain conditions in constructed wetlands (e.g., Rahman et al., 2019). While we did not consider nutrient loads, even if nutrient concentrations increase through constructed wetlands, the net nutrient load may decrease due to water losses through evapotranspiration and/or seepage. Effluent concentrations were most strongly correlated with influent concentrations for both $\mathrm{N}$ species (Spearman rho $=0.9, \mathrm{p}<0.0001$ ) and $\mathrm{P}$ species (Spearman rho $=0.8, \mathrm{p}<0.0001)$.
Of the wetland design characteristics extracted from the collection of studies compiled herein, we anticipated positive correlations between nutrient reductions and design attributes that result in longer HRTs because contact time is an important factor in denitrification (Kadlec and Knight, 1996). Ensuring that wetlands are large enough relative to their contributing drainage area is one way to provide longer HRTs. In the data compiled here, nutrient concentration reduction rates were positively correlated with the treatment area ratio for both TN and TP (Spearman rho $=0.36$ and 0.45 , respectively; $\mathrm{p}<0.05$ ). However, direct relationships with HRT were mixed. For N species, longer retention times were associated with lower effluent concentrations. The reverse was true for dissolved $\mathrm{P}$, for which longer retention times were associated with higher effluent concentrations (Spearman's rho $=0.42 ; \mathrm{p}<0.05$ ). Total $\mathrm{P}$ concentrations were not significantly associated with HRT. The relationships between nutrient reductions and HRT observed across this dataset align with expectations that longer retention times promote denitrification, which is the primary removal mechanism for $\mathrm{N}$ removal, but may also indicate that longer retention times promote sorbed $\mathrm{P}$ release and/or other internal $\mathrm{P}$ cycling processes. However, other researchers have observed positive correlations between HRT and reductions in P concentrations. For example, Reinhardt et al. (2005) reported increasing retention of dissolved $\mathrm{P}$ with increasing HRT for influent concentrations ranging up to $0.1 \mathrm{mg} \mathrm{L}^{-1}$, although percentage reductions for influent DIP concentrations $<0.004 \mathrm{mg} \mathrm{L}^{-1}$ tended to be negative for HRTs less than 20 days. The correlations between observed nutrient reductions and HLR in our dataset were relatively weak and not statistically significant. It is likely that other influential variables that were not accounted for in this analysis precluded detection of simplistic relationships between HRT or HLR and nutrient reduction performance across this dataset. For example, most of the variability in $\mathrm{NO}_{3}-\mathrm{N}$ reduction performance observed in monitoring data from a set of 33 wetlands restored to treat tile drainage from cropland in north central Iowa was explained using nonlinear models incorporating HLR and water temperature as predictive variables (Crumpton et al., 2006; Crumpton and Stenback, 2018). In addition to seasonal differences in water temperature, other researchers have found that substrate organic matter, which can be enhanced through organic amendments at construction and/or accumulated through time, positively influenced 
$\mathrm{NO}_{3}-\mathrm{N}$ removal rates by constructed wetlands (e.g., (Burchell et al., 2007; Messer et al., 2017a; Spieles and Mitsch, 1999). While the importance of factors such as these is indicated by previous studies, they were not included in this analysis due to lack of consistent reporting across the compiled studies.

Of the nutrient forms examined, $\mathrm{NO}_{3}-\mathrm{N}$ removal rates were highest as well as the most cost-effective (initial installation and annual maintenance costs). This is not surprising, given the potential for denitrification under the anaerobic conditions characteristic of wetland sediments (Kadlec and Wallace, 2009). However, the corresponding low removal rates for $\mathrm{NH}_{4}-\mathrm{N}$ indicate a need to improve wetland designs with aerobic zones intended to promote transformation of $\mathrm{NH}_{4}-\mathrm{N}$ to $\mathrm{NO}_{3}-\mathrm{N}$ prior to denitrification, such as verticalflow wetland designs, aerators, and control of plant type and density, $\mathrm{pH}$, and temperature (Jamieson et al., 2003; Uggetti et al., 2016; Zhang et al., 2011). As indicated in table 1, $\mathrm{NH}_{4}-$ $\mathrm{N}$ comprised only about $10 \%$ of the influent and effluent TN concentrations in the studies reviewed herein, so site-specific cost-benefit analyses need to guide any design improvements aimed at $\mathrm{NH}_{4}-\mathrm{N}$ enhancement.

Further understanding of the influence of design factors such as treatment area ratio and HRT could be gained if all studies reported this information. Of the studies identified for this analysis, roughly half reported design and operating details such as this. This relative lack of data constitutes a weakness of this assessment, and we encourage all study authors to report salient design details along with pollutant removal and other performance metrics. In addition to treatment area ratios and HRT, reporting the $\mathrm{P}$ content and cation exchange capacity of wetland soils could also improve understanding of how the finite sorption capacities of constructed wetlands influence long-term dissolved $\mathrm{P}$ removal (Mitsch and Gosselink, 2015). This could be especially important for wetlands constructed on former cropland areas with high soil $\mathrm{P}$.

\section{CONSTRUCTED WETLANDS FOR LIVESTOCK WASTEWATER}

Constructed wetlands are used throughout the world for agricultural wastewater management (Knight et al., 2000). We reviewed 15 studies that described a total of 52 constructed wetland designs for livestock, including 40 swine systems (Bayo et al., 2012; Borin et al., 2013; González et al., 2009; Finlayson et al., 1987; Humenik et al., 1999; Hunt et al., 1993; Lee et al., 2004, 2010; Luo et al., 2017; Meers et al., 2005; Poach et al., 2003, 2004, 2007; Stone et al., 2004), eleven dairy systems (Kadlec et al., 2005; Moreira et al., 2010), and one duck system (Lu et al., 2008). A complete table of the design components for each of the reviewed studies can be found in the supplemental material. The constructed wetland designs included horizontal subsurface flow, surface flow, and combinations of horizontal subsurface flow and surface flow. Wetland sizes ranged from 10 to 1,500 ha with retention times from 0.6 to 120 days. Table 2 presents a summary of the nutrient removal data from the reviewed livestock studies. TN and TP were the two primary nutrient measurements reported in these studies and had percentage removals ranging from $21 \%$ to $70 \%$ and from $-101 \%$
Table 2. Median influent and effluent total nitrogen (TN) and total phosphorus (TP) concentrations $\left(\mathrm{mg} \mathrm{L}^{-1}\right)$ and percentage removals reported for constructed wetlands treating livestock manure.

\begin{tabular}{|c|c|c|}
\hline Nutrient Source & $\mathrm{TN}$ & $\mathrm{TP}$ \\
\hline \multicolumn{3}{|l|}{ Subsurface flow ( $n=5$ studies) } \\
\hline Influent (mg L'-1) & N/A & $\begin{array}{c}126 \\
(43.6 \text { to } 169) \\
\end{array}$ \\
\hline Effluent (mg L $\left.{ }^{-1}\right)$ & N/A & $\begin{array}{c}27 \\
(13 \text { to } 50) \\
\end{array}$ \\
\hline Removal (\%) & $\begin{array}{c}52 \\
\text { (21 to } 70) \\
\end{array}$ & $\begin{array}{c}13 \\
(-101 \text { to } 79) \\
\end{array}$ \\
\hline \multicolumn{3}{|l|}{ Surface flow ( $n=10$ studies) } \\
\hline Influent $\left(\mathrm{mg} \mathrm{L}^{-1}\right)$ & N/A & $\begin{array}{c}43 \\
\text { (5.5 to } 73)\end{array}$ \\
\hline Effluent (mg L $\left.{ }^{-1}\right)$ & N/A & $\begin{array}{c}27 \\
\text { (3 to } 66) \\
\end{array}$ \\
\hline Removal (\%) & $\begin{array}{c}43 \\
\text { (22 to } 63) \\
\end{array}$ & $\begin{array}{c}40 \\
(7 \text { to } 89) \\
\end{array}$ \\
\hline
\end{tabular}

to $89 \%$, respectively. Similar to the cropland evaluation, $\mathrm{N}$ removal had higher percentage removals compared to TP. However, these observations were likely due to exceedingly high TP influent concentrations in systems with limited oxygenation incorporated into the wetland design. Additionally, differences in influent composition for different animal species resulted in higher variability; further information is available in the supplemental material. However, all data were combined for table 2 , given the significant variability in wetland design and wetland influents for the reviewed livestock studies.

Constructed wetlands are considered relatively low-cost and low-maintenance opportunities for livestock wastewater management, specifically in regions with limited land for spreading manure (Harrington et al., 2012). The greatest challenges for the operation and continued performance of these systems include clogging (De la Varga et al., 2013), managing the large footprint (Masi et al., 2017), and the limited P adsorption capacity (Mankin and Ikenberry, 2004). However, potential solutions to improve nutrient treatment and reduce the footprint include optimizing the oxygen input in aerated constructed wetland stages (Masi et al., 2017), incorporating carbon dosing schedules (Saeed and Sun, 2012), recirculating wastewater (Saeed and Sun, 2012), integrating intermittent aeration (Wu et al., 2015), and periodically harvesting vegetation (Vymazal, 2009). Similar to the cropland review, reporting of design factors is imperative to further our understanding of the influence of design factors on treatment efficiencies.

\section{CONSTRUCTED WETLANDS FOR GREENHOUSE WASTEWATER}

Nursery and greenhouse runoff can contribute significant nutrient loads to receiving waters with a wide range of $\mathrm{NO}_{3}$ $\mathrm{N}$ concentrations $\left(<1\right.$ to $\left.>380 \mathrm{mg} \mathrm{L}^{-1}\right)$ and event flow volumes (2,500 to $110,000 \mathrm{~L}$; McMaine et al., 2020; Wilson et al., 2010). Relatively inefficient overhead irrigation systems over relatively impervious surfaces, coupled with regular irrigation (daily during growing seasons, every two to seven days during non-growing seasons) can create large volumes of runoff from greenhouse systems (Beeson and Knox, 1991; McMaine et al., 2020; Wilson et al., 2010). To date, there has been limited research on constructed wetlands as a management tool for plant nursery and greenhouse runoff (e.g., 
Table 3. Mean influent and effluent nitrogen $\left(\mathrm{TN}=\right.$ total nitrogen, $\mathrm{NO}_{3}-\mathrm{N}=$ nitrate-N, and $\mathrm{NH}_{4}-\mathrm{N}=$ ammonium-N) and phosphorus $(\mathrm{TP}=$ total phosphorus, and DIP = dissolved inorganic phosphate) concentrations $\left(\mathrm{mg} \mathrm{L}^{-1}\right)$ and percentage removals reported for constructed wetlands treating greenhouse effluent (minimum/maximum values shown in parentheses).

\begin{tabular}{|c|c|c|c|c|c|c|c|c|}
\hline Nutrient Source & $\begin{array}{c}\mathrm{TN} \\
(n=1)\end{array}$ & $\begin{array}{l}\mathrm{NO}_{3}-\mathrm{N} \\
(n=5)\end{array}$ & $\begin{array}{l}\mathrm{NO}_{2}-\mathrm{N} \\
(n=4)\end{array}$ & $\begin{array}{c}\mathrm{NO}_{2}-\mathrm{N} \\
+\mathrm{NO}_{3}-\mathrm{N} \\
(n=0)\end{array}$ & $\begin{array}{l}\mathrm{NH}_{3}-\mathrm{N} \\
(n=0)\end{array}$ & $\begin{array}{l}\mathrm{NH}_{4}-\mathrm{N} \\
(n=4)\end{array}$ & $\begin{array}{c}\mathrm{TP} \\
(n=5)\end{array}$ & $\begin{array}{c}\text { DIP } \\
(n=1)\end{array}$ \\
\hline \multicolumn{9}{|l|}{ Subsurface flow ( $n=5$ studies) } \\
\hline Influent (mg L $\left.{ }^{-1}\right)$ & 0.8 & $\begin{array}{c}80.9 \\
(0.67 / 101) \\
\end{array}$ & $\begin{array}{c}2.4 \\
(2.4 / 2.4)\end{array}$ & N/A & N/A & $\begin{array}{c}24.8 \\
(24.8 / 24.8)\end{array}$ & $\begin{array}{c}4.0 \\
(0.09 / 5)\end{array}$ & 0.09 \\
\hline Effluent $\left(\mathrm{mg} \mathrm{L}^{-1}\right)$ & 0.5 & $\begin{array}{c}0.4 \\
(0.1 / 1.21)\end{array}$ & $\begin{array}{c}0 \\
(0 / 0)\end{array}$ & N/A & N/A & $\begin{array}{c}16.3 \\
(11 / 24.8) \\
\end{array}$ & $\begin{array}{c}2.1 \\
(0.07 / 3.17) \\
\end{array}$ & 0.087 \\
\hline Removal (\%) & 37.5 & $\begin{array}{c}87 \\
(36.6 / 99.9) \\
\end{array}$ & $\begin{array}{c}100 \\
(100 / 100)\end{array}$ & N/A & N/A & $\begin{array}{c}34.4 \\
(0 / 55.5)\end{array}$ & $\begin{array}{c}42.7 \\
(20 / 71)\end{array}$ & 3.3 \\
\hline Nutrient Source & $\begin{array}{c}\mathrm{TN} \\
(n=1)\end{array}$ & $\begin{array}{l}\mathrm{NO}_{3}-\mathrm{N} \\
(n=3)\end{array}$ & $\begin{array}{l}\mathrm{NO}_{2}-\mathrm{N} \\
(n=2)\end{array}$ & $\begin{array}{c}\mathrm{NO}_{2}-\mathrm{N} \\
+\mathrm{NO}_{3}-\mathrm{N} \\
(n=1) \\
\end{array}$ & $\begin{array}{l}\mathrm{NH}_{3}-\mathrm{N} \\
(n=2)\end{array}$ & $\begin{array}{l}\mathrm{NH}_{4}-\mathrm{N} \\
(n=0)\end{array}$ & $\begin{array}{c}\mathrm{TP} \\
(n=1)\end{array}$ & $\begin{array}{c}\text { DIP } \\
(n=2)\end{array}$ \\
\hline \multicolumn{9}{|l|}{ Surface flow ( $n=5$ studies) } \\
\hline Influent $\left(\mathrm{mg} \mathrm{L}^{-1}\right)$ & 1.8 & $\begin{array}{c}9.2 \\
(0.8 / 16.1) \\
\end{array}$ & $\begin{array}{c}1.1 \\
(0.82 / 1.4) \\
\end{array}$ & 9 & $\begin{array}{c}2.5 \\
(1.46 / 3.51) \\
\end{array}$ & N/A & 0.32 & $\begin{array}{c}0.86 \\
(0.27 / 1.45) \\
\end{array}$ \\
\hline Effluent (mg L $\left.{ }^{-1}\right)$ & 1.4 & $\begin{array}{c}4.1 \\
(0.64 / 7.73) \\
\end{array}$ & $\begin{array}{c}0.27 \\
(0.16 / 0.37) \\
\end{array}$ & 1.56 & $\begin{array}{c}0.66 \\
(0.52 / 0.8) \\
\end{array}$ & N/A & 0.23 & $\begin{array}{c}0.84 \\
(0.2 / 1.48) \\
\end{array}$ \\
\hline Removal (\%) & 22.2 & $\begin{array}{c}44.9 \\
(20 / 62.8)\end{array}$ & $\begin{array}{c}71.6 \\
(54.9 / 88)\end{array}$ & 82.7 & $\begin{array}{c}70.7 \\
(64.4 / 77)\end{array}$ & N/A & 28 & $\begin{array}{c}11.8 \\
(-2.4 / 25.9)\end{array}$ \\
\hline
\end{tabular}

Beeson and Knox, 1991; Narváez et al., 2011; White, 2017), and we were only able to identify five studies for this review (McMaine et al., 2020; Narváez et al., 2011; Taylor et al., 2006; White, 2017; White et al., 2010).

Of the studies reviewed, constructed wetlands significantly reduced nutrient loadings from nursery and greenhouse runoff (table 3). Taylor et al. (2006) monitored a 3.77 ha surface-flow constructed wetland treating runoff from a 48.6 ha container nursery plot over 38 months. The system reduced $\mathrm{NO}_{3}-\mathrm{N}$ concentrations by $94.7 \%$ from March to November and by $70.7 \%$ during the remainder of the year when water temperatures decreased below $15^{\circ} \mathrm{C}$. By comparison, DIP concentrations were not significantly changed by the constructed wetland. Narváez et al. (2011) researched constructed wetlands with removal rates in excess of $98.8 \%$ for $\mathrm{NO}_{3}-\mathrm{N}$ and TP removals of $40 \%$ to $99 \%$. McMaine et al. (2020) measured $86 \%, 85 \%, 79 \%$, and $78 \%$ mass reductions for $\mathrm{NO}_{3}-\mathrm{N}, \mathrm{TN}, \mathrm{PO}_{4}-\mathrm{P}$, and TP, respectively, for a horizontal subsurface-flow constructed wetland and $47 \%, 17 \%, 47 \%$, and $46 \%$ mass reductions for $\mathrm{NO}_{3}-\mathrm{N}, \mathrm{TN}, \mathrm{PO}_{4}-\mathrm{P}$, and $\mathrm{TP}$, respectively, for a surface-flow constructed wetland. For two surface-flow wetlands, White et al. (2010) examined the effects of HRT and seasonal nutrient loading (internal and external nutrient sources) and reported that the $\mathrm{TN}$ removal efficiency for concentration ranged from $52 \%$ to $98 \%$, and lower hydraulic loadings and longer HRTs resulted in higher removal rates. A key observation was that consistent inflow rates were critical for maintaining system performance. Denitrification accounted for $63 \%$ to $99 \%$ of $\mathrm{N}$ removal in that study (White et al., 2010). White (2017) determined that $\mathrm{N}$ speciation in nursery runoff was approximately $45 \% \mathrm{NO}_{3}-\mathrm{N}$, $45 \% \mathrm{NH}_{4}-\mathrm{N}$, and $10 \%$ urea $\mathrm{N}$. Thus, systems with both aerobic and anaerobic zones that promote nitrification upstream of denitrification would be expected to be most efficient.

\section{CONSTRUCTEd Wetlands For OPEN-AIR PONDS AND AQUACUlture WASTEWATER}

Aquaculture refers to the production of freshwater or marine species such as fish, shellfish, aquatic plants, and algae. It is the fastest growing protein sector in the world (Ahmed and Thompson, 2019). While effluents from aquaculture systems tend to have lower nutrient concentrations compared to livestock systems, the growth of the aquaculture industry and its potential to negatively impact freshwater and estuarine ecosystems have created interest in constructed wetlands as potentially cost-effective treatment systems (e.g., Van Rijn, 1996, 2013). Much of the research conducted to characterize the performance of wetlands treating aquaculture waste streams has been conducted at the microcosm or pilot scale (e.g., Gorito et al., 2018; Li and Tao, 2017; Li et al., 2019; Lin et al., 2002; Summerfelt et al., 1999; Webb et al., 2013). However, ten studies documenting wetland performance at scales relevant to commercial aquaculture were identified in this review. These studies included surface flow, subsurface flow, and hybrid systems applied to treat effluents from saline mariculture systems (Shpigel et al., 2013), brackish effluents from recirculating shrimp production systems (Lin et al., 2005, 2010; Tilley et al., 2002), and recirculating freshwater ponds or tanks for tilapia and trout production (Buric et al., 2015; Konnerup et al., 2011; Schwartz and Boyd, 1995; Zachritz et al., 2008; Zhang et al., 2010). Table 4 summarizes the data from these studies; details are provided in the supplemental material. Due to the relatively small dataset and the lack of significant differences between influent or effluent concentrations reported for the various hydraulic designs (e.g., surface vs. subsurface flow), we combined all nutrient performance data for constructed wetlands treating aquaculture effluents in table 4.

As indicated in table 4, nutrient retention by wetlands treating aquaponic effluent streams was highest for $\mathrm{NO}_{3}-\mathrm{N}$ and TP. It has been suggested that the relatively consistent loading rates from aquaculture systems can support more consistent levels of saturation, thus maintaining redox conditions that promote denitrification ( $\mathrm{Li}$ and Tao, 2017; van Rijn et al., 2006), although the mean $\mathrm{NO}_{3}-\mathrm{N}$ reductions compiled for wetlands treating aquaculture effluents were similar to the rates observed for runoff-driven cropland systems. The mean percentage removal for $\mathrm{NH}_{4}-\mathrm{N}$ indicated that $\mathrm{NH}_{4}-\mathrm{N}$ was generally transformed or removed by aquaponic treatment wetlands. However, this result was skewed by a 
Table 4. Mean nitrogen ( $\mathrm{TN}=$ total nitrogen, $\mathrm{NO}_{3}-\mathrm{N}=$ nitrate-N, and $\mathrm{NH}_{4}-\mathrm{N}=$ ammonium-N) and phosphorus $(\mathrm{TP}=$ total phosphorus, and DIP $=$ dissolved inorganic phosphate) concentrations $\left(\mathrm{mg} \mathrm{L}^{-1}\right)$ and percentage removals reported for constructed wetlands treating aquaculture effluent (minimum/maximum values shown in parentheses).

\begin{tabular}{|c|c|c|c|c|c|c|}
\hline Nutrient Source & & $\mathrm{TN}$ & $\mathrm{NO}_{3}-\mathrm{N}$ & $\mathrm{NH}_{4}-\mathrm{N}$ & $\mathrm{TP}$ & DIP \\
\hline \multirow{3}{*}{$\begin{array}{l}\text { Aquaculture effluent } \\
\quad(n=10 \text { studies })\end{array}$} & Influent (mg L-1) & $\begin{array}{c}5.5 \\
(1.2 / 9.6) \\
\end{array}$ & $\begin{array}{c}2.44 \\
(0.04 / 5.6) \\
\end{array}$ & $\begin{array}{c}0.76 \\
(0.08 / 5.1) \\
\end{array}$ & $\begin{array}{c}1.02 \\
(0.0 / 4.2) \\
\end{array}$ & $\begin{array}{c}0.63 \\
(0.02 / 1.4) \\
\end{array}$ \\
\hline & Effluent $\left(\mathrm{mg} \mathrm{L}^{-1}\right)$ & $\begin{array}{c}5.1 \\
(0.6 / 10.8) \\
\end{array}$ & $\begin{array}{c}0.68 \\
(0 / 5.8) \\
\end{array}$ & $\begin{array}{c}0.82 \\
(0 / 4.8) \\
\end{array}$ & $\begin{array}{c}0.92 \\
(0.02 / 4.4) \\
\end{array}$ & $\begin{array}{c}0.71 \\
(0.02 / 1.6) \\
\end{array}$ \\
\hline & Removal (\%) & $\begin{array}{c}21 \\
(-25 / 67) \\
\end{array}$ & $\begin{array}{c}43 \\
(-4 / 100) \\
\end{array}$ & $\begin{array}{c}18 \\
(-122 / 100) \\
\end{array}$ & $\begin{array}{c}30.2 \\
(-4 / 100) \\
\end{array}$ & $\begin{array}{c}-3.9 \\
(-35.3 / 33) \\
\end{array}$ \\
\hline
\end{tabular}

small number of data points for which removal was very high (nearly $100 \%$ ). In general, the $\mathrm{NH}_{4}-\mathrm{N}$ concentrations discharged from this sample of wetland systems were relatively similar to the influent concentrations. The strongest determinant of effluent $\mathrm{N}$ concentrations across this set of ten studies was influent concentration; HRT, HLR and wetland area did not exert any appreciable effect. This result may be a product of the relatively small sample size, but it may also indicate opportunities to promote diverse microbiomes and associated microbially mediated $\mathrm{N}$ cycling processes through wetland design (e.g., Chen et al., 2019; Pelissari et al., 2018). While the TP concentrations discharged from this set of treatment wetlands were generally lower than the influent concentrations, dissolved P forms changed little or increased in concentration. Further investigation of substrate composition, vegetative cover, seasonality, and other environmental factors is needed to better incorporate mechanisms for retaining DIP in wetlands constructed for the aquaculture industry.

\section{CONSTRUCTED WETLANDS FOR HYDROPONIC WASTEWATER}

Hydroponic systems produce crops using mineral nutrient solutions, generally in the absence of soil. The hydroponic solution is recirculated through the system, typically several times, before being discharged as wastewater (Park et al., 2009). The solution must be changed frequently to maintain high nutrient concentrations while avoiding pests and diseases. Wastewater from hydroponic agriculture, referred to hereafter as HWW, tends to be high in $\mathrm{NO}_{3}-\mathrm{N}(200$ to $>300$ $\mathrm{mg} \mathrm{L}^{-1}$ ) and DIP (15 to $100 \mathrm{mg} \mathrm{P} \mathrm{L}^{-1}$ ) but relatively low in organic carbon (Park et al., 2008, 2009). The use of constructed wetlands to treat HWW is an emerging area with limited research. The most common configuration for treating HWW has been horizontal subsurface-flow constructed wetlands with HRTs of 2 to 3 days. However, HWW requires organic matter subsidies to facilitate treatment.

From a treatment perspective, low carbon-to-nitrogen (C:N) ratios limit the potential for $\mathrm{N}$ removal via denitrification. Thus, to drive the biological process, it is generally necessary to add an electron donor. Thiosulfate and elemental sulfur are two electron donors that have been shown to support autotrophic denitrification in wetlands treating HWW; however, thiosulfate has potential to produce excessive sulfate concentrations ( $\left.>200 \mathrm{mg} \mathrm{L}^{-1}\right)$ (Park et al., 2015). Organic debris (crop residue, wood chips, plant sap, etc.) and other carbon sources (methanol, ethanol, sucrose, fructose, or acetic acid) have also been used to effectively increase $\mathrm{C}: \mathrm{N}$ ratios and stimulate denitrification in these systems (Park et al., 2008, 2015). With a sufficient electron donor supply, $\mathrm{NO}_{3}-\mathrm{N}$ removal rates have ranged from $7 \%$ to $>72 \%$, generally achieving effluent concentrations $<80 \mathrm{mg} \mathrm{N} \mathrm{L}^{-1}$ (Gagnon et al., 2010; Park et al., 2008, 2015). Removal of DIP has ranged from $6 \%$ to $89 \%$, with final concentrations of 1.7 to $54 \mathrm{mg} \mathrm{P} \mathrm{L}^{-1}$ (table 5). Plants have also been shown to improve removal of $\mathrm{NO}_{3}-\mathrm{N}, \mathrm{NH}_{4}-\mathrm{N}$, and DIP in horizontal subsurface-flow constructed wetlands treating HWW (Gagnon et al., 2010; Park et al., 2015).

Hydroponic systems typically have small footprints and are often sited in areas where space is limited, and it would stand to reason that the treatment of HWW would face similar constraints. Conventional constructed wetlands with large surface areas and long retention times may not be the most effective realization of this technology for treating HWW. Instead, modularized horizontal subsurface-flow constructed wetlands with shorter HRTs and controlled dosing of carbon or electron donor inputs to meet set discharge criteria would likely be more successful. As agriculture technologies evolve and hydroponic applications become a larger sector of crop production, the high nutrient concentration byproduct will become a larger management issue for the industry and a key to future sustainability.

\section{GEOGRAPHIC USAGE AND DESIGN OF Constructed WeTlands}

This synthesis offers a broad view of constructed wetland performance in the context of varied agricultural systems, but treatment efficiencies reported in the literature are nuanced by a range of geographic factors, such as climate and soil type. To determine the degree to which the reviewed

Table 5. Mean influent and effluent nitrogen $\left(\mathrm{TN}=\right.$ total nitrogen, $\mathrm{NO}_{3}-\mathrm{N}=$ nitrate- $\mathrm{N}$, and $\mathrm{NH}_{4}-\mathrm{N}=$ ammonium-N) and phosphorus $(\mathrm{TP}=$ total phosphorus, and DIP = dissolved inorganic phosphate) concentrations $\left(\mathrm{mg} \mathrm{L}^{-1}\right)$ and percentage removals reported for constructed wetlands treating hydroponic effluent (minimum/maximum values shown in parentheses).

\begin{tabular}{|c|c|c|c|c|c|c|}
\hline Nutrient Source & & $\mathrm{TN}$ & $\mathrm{NO}_{3}-\mathrm{N}$ & $\mathrm{NH}_{4}-\mathrm{N}$ & $\mathrm{TP}$ & DIP \\
\hline \multirow{3}{*}{$\begin{array}{l}\text { Subsurface flow } \\
\qquad(n=2)\end{array}$} & Influent mean $\left(\mathrm{mg} \mathrm{L}^{-1}\right)$ & $\mathrm{N} / \mathrm{A}$ & $\begin{array}{c}188.76 \\
(136 / 228)\end{array}$ & $\begin{array}{c}16.50 \\
(16 / 17)\end{array}$ & N/A & $\begin{array}{c}39.38 \\
(15 / 58)\end{array}$ \\
\hline & Effluent mean $\left(\mathrm{mg} \mathrm{L}^{-1}\right)$ & N/A & $\begin{array}{c}103.71 \\
(39 / 213) \\
\end{array}$ & $\begin{array}{c}7.50 \\
(6 / 10) \\
\end{array}$ & N/A & $\begin{array}{c}28.32 \\
(1.7 / 54) \\
\end{array}$ \\
\hline & Removal (\%) & N/A & $\begin{array}{l}47.81 \\
(7 / 72)\end{array}$ & $\begin{array}{c}57.25 \\
(44 / 68)\end{array}$ & N/A & $\begin{array}{l}44.59 \\
(6 / 89)\end{array}$ \\
\hline
\end{tabular}


literature included analyses from a range of climate and ecoregions, the locations associated with the study sites of reviewed articles were tabulated (in the supplemental material), with a specific focus on analyses that assessed constructed wetlands as agricultural cultural practices (ACPs) for nutrient treatment in cropland, drained lands, and livestock production systems. The majority of studies reviewed in this synthesis originated from the U.S., followed by Europe, Asia, and Oceania (fig. 1). Among the studies that analyzed constructed wetlands in the U.S., the majority focused on systems in Illinois, North Carolina, and Florida (fig. 2). Although Illinois, North Carolina, and Florida are home to extensive agricultural lands, the insights gained from assessments of sites in these states may not be broadly representative of the diverse production systems present throughout the U.S. Similarly, undocumented analyses from other parts of the world, such as South America and Africa, signals that further research is needed to understand how constructed wetland designs should vary as a function of diverse agricultural landscapes.
Overall removal of nutrients entering constructed wetlands in livestock manure and cropland runoff waters were assessed (table 6). All data were fit linearly, with two requiring normalization. Removal of nutrient species was observed in all fit relationships between influent and effluent concentrations of constructed wetlands regardless of wetland design. $\mathrm{R}^{2}$ values ranged from 0.382 to 0.723 , with all having $\mathrm{p}$-values of $\leq 0.02$. Lower $\mathrm{R}^{2}$ values likely reflect performance variability associated with factors such as temperature, design, and dissolved oxygen differences among systems. Factors such as these were not included in this analysis as they were not reported in the majority of published articles. Assessments of HRT, HLR, and wetland area were assessed but did not provide strong relationships, particularly for TN, $\mathrm{NO}_{3}-\mathrm{N}$, and TKN (table 7). However, stronger relationships, specifically between DIP, TP, and $\mathrm{NH}_{4}-\mathrm{N}$, were found for HRT along with HLR and wetland area, dependent on analyte (tables 7 and 8). Considerable variability in nutrient removal performance within and among the reviewed studies was observed. This variability
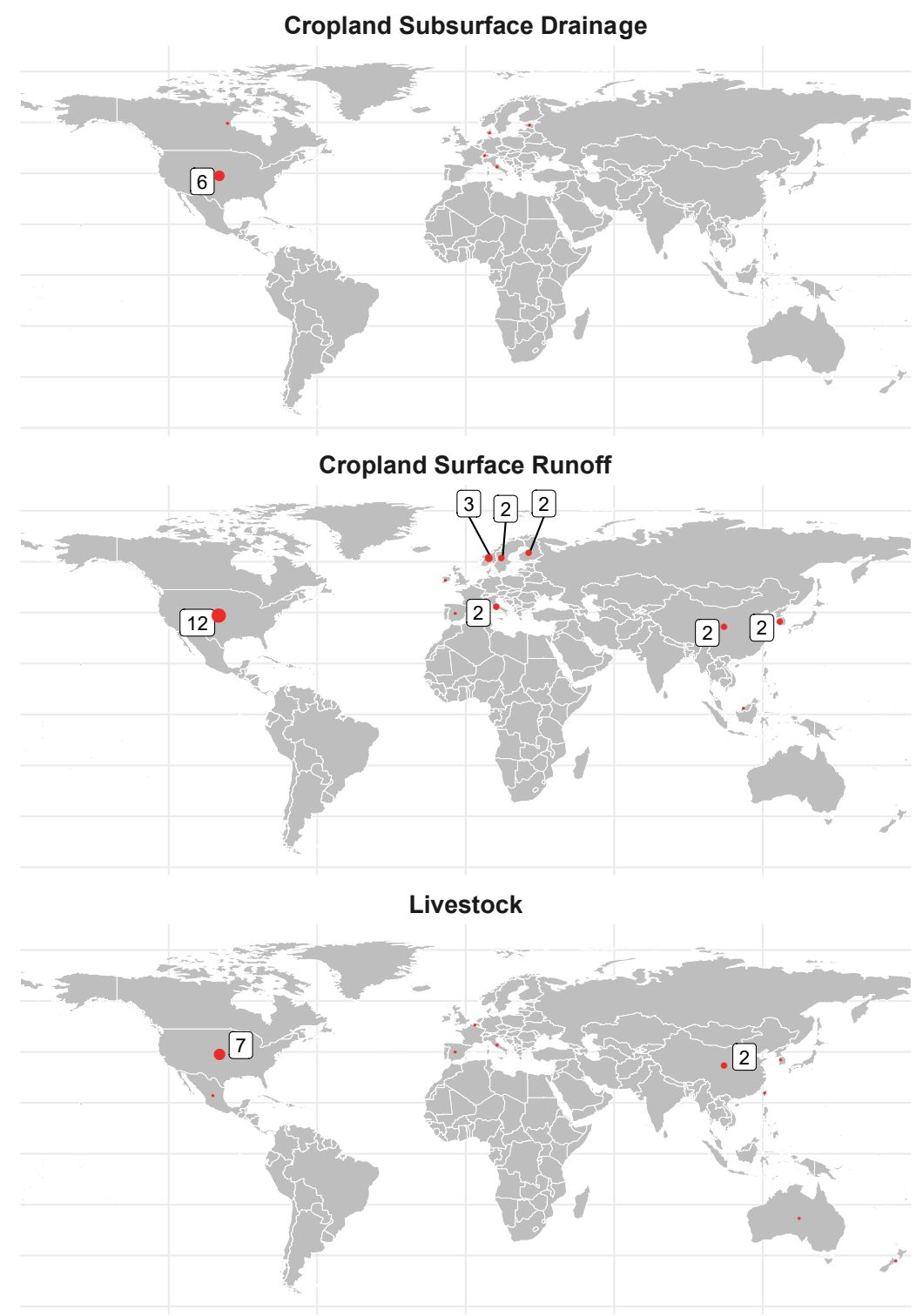

Figure 1. Global study sites of constructed wetlands reviewed in this synthesis article. 


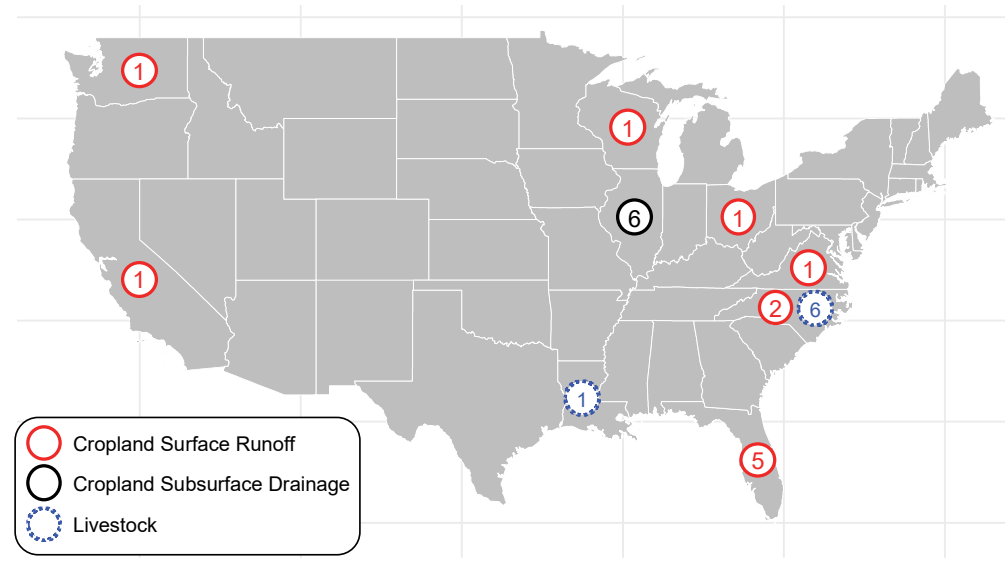

Figure 2. Study sites of constructed wetlands in the U.S. reviewed in this synthesis article. Sites shown in red, blue, and black are sites that treated influent from cropland runoff, drainage outflow, and livestock manure, respectively.

Table 6. Statistical analysis including p-values, adjusted $\mathrm{R}^{2}$, and regression equations for influent and effluent nutrient species $\left(\mathrm{NO}_{3}-\mathrm{N}=\mathbf{n i t r a t e -}\right.$ $\mathrm{N}, \mathrm{TN}=$ total nitrogen, $\mathrm{TKN}=$ total Kjeldahl nitrogen, $\mathbf{T P}=$ total phosphorus, and DIP $=$ dissolved inorganic phosphate, $\left.\mathrm{mg}^{-1}\right)$ relationships with varying influent types $\left(C_{e}=\right.$ effluent concentration, and $C_{i}=$ influent concentration).

\begin{tabular}{|c|c|c|c|c|c|c|c|c|c|c|}
\hline & \multicolumn{4}{|c|}{ Drainage } & \multicolumn{4}{|c|}{ Runoff } & \multicolumn{2}{|c|}{ Livestock } \\
\hline & $\mathrm{NO}_{3}-\mathrm{N}$ & TN & DIP & TP & $\mathrm{NO}_{3}-\mathrm{N}$ & TN & DIP & TP & TKN & TP \\
\hline p-Value & $<0.001$ & $<0.001$ & $<0.001$ & $<0.001$ & $<0.001$ & $<0.001$ & $<0.001$ & $<0.001$ & 0.02 & $<0.001$ \\
\hline Adj. $R^{2}$ & 0.403 & 0.717 & 0.382 & 0.600 & 0.674 & 0.584 & 0.589 & 0.609 & 0.5584 & 0.723 \\
\hline $\begin{array}{c}\text { Regression } \\
\text { equation }\end{array}$ & $\begin{array}{c}C_{e}= \\
0.864+ \\
0.6209 C_{i}\end{array}$ & $\begin{array}{c}C_{e}= \\
-0.096+ \\
0.7893 C_{i}\end{array}$ & $\begin{array}{c}\ln \left(C_{e}\right)= \\
-1.048+ \\
0.6124 C_{i}\end{array}$ & $\begin{array}{c}\ln \left(C_{e}\right)= \\
-0.7133+ \\
0.6278 C_{i}\end{array}$ & $\begin{array}{c}C_{e}= \\
0.1031+ \\
0.5736 C_{i}\end{array}$ & $\begin{array}{c}C_{e}= \\
1.301+ \\
0.5365 C_{i}\end{array}$ & $\begin{array}{c}\ln \left(C_{e}\right)= \\
-0.2505+ \\
1.121 C_{i}\end{array}$ & $\begin{array}{c}\ln \left(C_{e}\right)= \\
-0.4053+ \\
1.103 C_{i}\end{array}$ & $\begin{array}{c}C_{e}= \\
-9.39+ \\
0.6220 C_{i}\end{array}$ & $\begin{array}{c}C_{e}= \\
-7.684+ \\
0.8058 C_{i}\end{array}$ \\
\hline
\end{tabular}

Table 7. Statistical analysis including p-values, adjusted $\mathrm{R}^{2}$, and regression equations for percentage removals of nitrogen species $\left(\mathrm{NO}_{3}-\mathrm{N}=\right.$ nitrate$\mathrm{N}, \mathrm{TN}=$ total nitrogen, $\mathrm{TKN}=$ total Kjeldahl nitrogen, and $\mathrm{NH}_{4}-\mathrm{N}=$ ammonium-N) relationships with hydraulic retention time (HRT, $\mathrm{h}$ ), hydraulic loading rate $\left(\mathrm{HLR}, \mathrm{cm} \mathrm{d}^{-1}\right)$, and wetland area $\left(\mathrm{WA}, \mathrm{m}^{2}\right)$ for drainage, runoff, and livestock wetlands.

\begin{tabular}{|c|c|c|c|c|c|c|c|c|c|c|c|c|}
\hline & \multicolumn{3}{|c|}{$\mathrm{NO}_{3}-\mathrm{N}$} & \multicolumn{3}{|c|}{ TN } & \multicolumn{3}{|c|}{ TKN } & \multicolumn{3}{|c|}{$\mathrm{NH}_{4}-\mathrm{N}$} \\
\hline & HLR & $\begin{array}{l}\text { HRT } \\
\end{array}$ & WA & HLR & $\begin{array}{l}\text { HRT } \\
\end{array}$ & WA & HLR & HRT & WA & $\mathrm{HLR}^{[\mathrm{a}]}$ & $\mathrm{HRT}^{[\mathrm{b}]}$ & WA \\
\hline p-Value & 0.082 & 0.216 & 0.06 & 0.307 & 0.052 & 0.71 & 0.178 & 0.614 & 0.276 & 0.011 & 0.042 & 0.286 \\
\hline Adj. $\mathrm{R}^{2}$ & 0.049 & 0.018 & 0.045 & 0.002 & 0.116 & 0.048 & 0.514 & $<0.000$ & 0.035 & 0.368 & 0.143 & 0.007 \\
\hline
\end{tabular}

[a] Regression equation: $\ln (\%$ Removal $)=-0.4664+0.8803 \times \ln (\mathrm{HLR})$

[b] Regression equation: $\ln (\%$ Removal $)=2.243-0.8018 \times \ln (\mathrm{HRT})$

Table 8. Statistical analysis including p-values, adjusted $\mathbf{R}^{2}$, and regression equations for percentage removals of phosphorus species (TP $=$ total phosphorus, and DIP $=$ dissolved inorganic phosphate $)$ relationships with hydraulic retention time (HRT, h), hydraulic loading rate $\left(\mathrm{HLR}, \mathrm{cm} \mathrm{d}^{-1}\right)$, and wetland area $\left(\mathrm{WA}, \mathrm{m}^{2}\right)$ for drainage, runoff, and livestock wetlands.

\begin{tabular}{|c|c|c|c|c|c|c|}
\hline & \multicolumn{3}{|c|}{ DIP } & \multicolumn{3}{|c|}{$\mathrm{TP}$} \\
\hline & HLR & $\mathrm{HRT}^{[\mathrm{a}]}$ & $\mathrm{WA}^{[\mathrm{b}]}$ & $\operatorname{HLR}^{[\mathrm{c}]}$ & $\mathrm{HRT}^{[\mathrm{d}]}$ & WA \\
\hline p-Value & 0.518 & 0.001 & 0.036 & 0.002 & 0.003 & 0.310 \\
\hline Adj. $R^{2}$ & $<0.001$ & 0.351 & 0.775 & 0.155 & 0.133 & 0.001 \\
\hline
\end{tabular}

[a] Regression equation: $\ln (\%$ Removal $)=0.8818+0.3346 \times \ln (\mathrm{HRT})$

[b] Regression equation: $\ln (\%$ Removal $)=1.613+0.09122 \times \ln (\mathrm{WA})$

[c] Regression equation: $\ln (\%$ Removal $)=1.814-0.1917 \times \ln (\mathrm{HLR})$

[d] Regression equation: $\ln (\%$ Removal $)=1.126+0.9150 \times \ln (\mathrm{HRT})$

highlights the need for further analysis of wetland design, climate, and other factors (i.e., denitrification parameters) that drive nutrient treatment processes, along with mass balance assessments rather than percentage removal evaluations. While we attempted to investigate other potential relationships between nutrient removal efficiency and other design factors (i.e., mass loading rate, average flow rate, and vegetation species; data found in the supplemental material), the reported design parameters were limited and did not allow definitive insights to be formed.

\section{COST-EFFECTIVENESS OF CONSTRUCTED WETLANDS}

Seven studies were identified in which capital and operating cost data for constructed wetlands treating runoff from cropland or livestock operations were reported. This relatively small dataset reflects actual costs (Gachango et al., 2015; Sano et al., 2005) or estimated costs (Christianson et al., 2013; Roley et al., 2016) for individual constructed wetlands as well as studies in which wetland construction and operating costs, as reported by federal and/or state environmental incentive programs (e.g., EQIP, CREP), were aggregated and reported to characterize wetland costs at watershed to regional scales (Hansen et al., 2015; Iovanna et al., 2008; Lentz et al., 2014). The wetlands in these studies were constructed to treat runoff or subsurface drainage from cropland and livestock facilities and were all surface-flow wetlands. Therefore, these costs may not be representative of systems designed to treat other agricultural effluents and/or subsurface-flow wetlands. The temporal scales over which wetland operating costs were considered ranged from 20 to 50 years, while the discount rates used to annualize costs ranged from $1.9 \%$ to $5 \%$. While all seven of these studies normalized economic costs on a per unit nutrient removal basis, only two of 


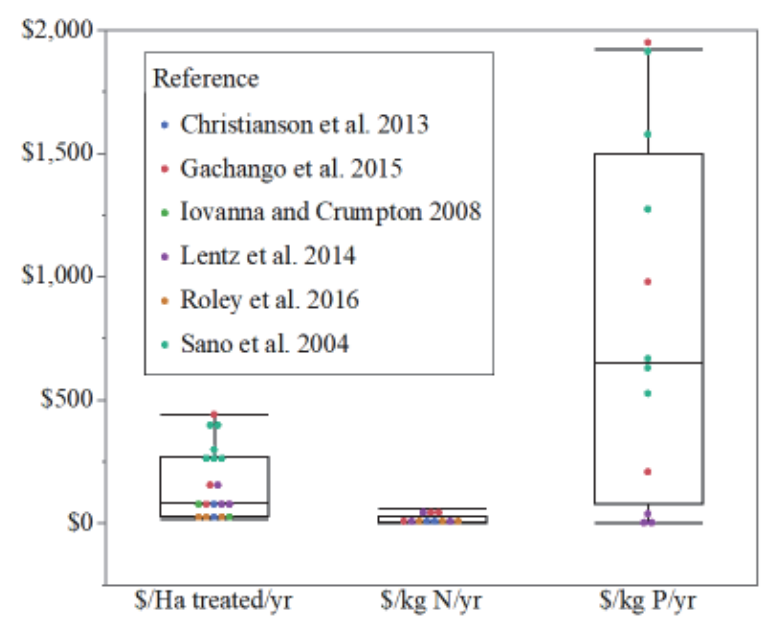

Figure 3. Box plots depicting reported life-cycle economic costs (in 2019 U.S. dollars) for agricultural constructed wetlands per hectare of contributing drainage area (i.e., area that drains to the wetland), per unit mass of nitrogen removed and per unit phosphorus removal.

these studies used nutrient removal performance data collected from the wetland for which the economic costs were tabulated. The remainder used modeled or literature-based values to characterize pollutant removal and associated economic effectiveness. Five of the seven studies considered removal efficiencies for one or more forms of $\mathrm{N}$, while only two considered $P$.

Resulting life cycle costs ranged from $\$ 18$ to $\$ 438$ ha $^{-1}$ contributing drainage area per year, with a mean value of $\$ 162$ ha $^{-1}$ treatment area year ${ }^{-1}$ (fig. 3). Nitrogen removal efficiencies reported in this collection of studies ranged from $\$ 0.66$ to $\$ 58 \mathrm{~kg}^{-1} \mathrm{~N}$ year ${ }^{-1}$ (mean $\$ 15.73 \mathrm{~kg}^{-1} \mathrm{~N}$ year ${ }^{-1}$ ). Reported $\mathrm{P}$ removal efficiencies were even more variable, ranging from $\$ 0.10$ to $\$ 1,923 \mathrm{~kg}^{-1} \mathrm{P}$ year ${ }^{-1}$ (mean $\$ 809.67 \mathrm{~kg}^{-1} \mathrm{P}$ year $^{-1}$ ). This variability can be partly explained by variability in the measured or assumed nutrient removal rates; for example, the $\mathrm{N}$ and $\mathrm{P}$ removal rates used by Lentz et al. (2014) spanned three orders of magnitude. Additional variability in reported costs associated with, for example, reliance of some systems on pumps, variation in site topography and associated excavation requirements and earthwork costs, and differences in foregone land rental costs included in the analyses also contributed to the observed spread in data.

\section{SUMMARY AND RECOMMENDATIONS FOR FUTURE WORK}

As reviewed herein, constructed wetlands have been shown to protect water quality in a wide range of agricultural production settings (e.g., cropland, livestock, greenhouse, aquaculture, and hydroponic systems). Although mean influent nutrient concentrations varied by one to two orders of magnitude across this set of unique agricultural production systems, mean percentage reductions in concentration were similar for $\mathrm{TN}(14 \%$ to $52 \%), \mathrm{NO}_{3}-\mathrm{N}(30 \%$ to $87 \%)$, and $\mathrm{TP}$ (13\% to $43 \%$ ). Mean DIP removal rates varied widely, with low $(-19 \%$ to $12 \%)$ retention rates for systems treating low influent DIP concentrations and high (45\%) rates for agricultural influents with high DIP concentrations. This result reflects a lower limit for DIP removal when influent concentrations approach so-called "irreducible concentrations" identified for wetland systems. This result also reflects a limitation of the percentage concentration methodology used as a performance metric in this study. $\mathrm{NO}_{3}-\mathrm{N}$ removal rates were generally higher than TN (mean rates of $30 \%$ to $87 \%$ across the five influent types considered), likely indicating the importance of anaerobic microbial $\mathrm{N}$ cycling pathways in these systems. The relative cost-effectiveness of nutrient removal for wetlands treating agricultural influent sources ranged from $\$ 0.66$ to $\$ 58 \mathrm{~kg}^{-1} \mathrm{~N}$ year-1 and from $\$ 0.10$ to $\$ 1,923 \mathrm{~kg}^{-1} \mathrm{P}$ year ${ }^{-1}$; however, cost studies were limited geographically and primarily reflected wetlands treating water from cropland systems.

Studies in the existing literature on constructed wetlands as ACPs for nutrient treatment in agricultural and aquacultural settings are not geographically extensive; of the 71 studies reviewed, the majority were from the U.S., Europe, Asia, and Oceania. Future research should focus on addressing knowledge and data gaps relative to the suite of factors that influence nutrient removal in constructed wetlands. Collaborations among researchers from across the world as well as more robust data collection would aid in documenting research efforts pertaining to the performance of constructed wetlands. Further, inconsistencies in constructed wetland characteristics reported in the literature suggest that standards are needed to ensure consistent nutrient removal goals depending on wetland design. We suggest that constructed wetland researchers report basic performance parameters, including influent and effluent concentrations, HRT, HLR, treatment area to contributing area ratio, plant species, design target (e.g., nutrient load removal), years in operation, percentage vegetative cover, soil media, soil organic matter percentage, and average operating water depth, in future published studies. Greater consistency among constructed wetland studies would support the creation of generalizable insights, which would help advance the use of constructed wetlands as agricultural ACPs. Additionally, emphasis of research on optimizing $\mathrm{NO}_{3}-\mathrm{N}$ removal has likely sacrificed conditions for DIP removal. Thus, further research on the tradeoffs between conditions optimized for removal of $\mathrm{NO}_{3}$ $\mathrm{N}$ and DIP or designing combined systems to create conditions suitable for removal of both nutrient species is needed. Further, similar syntheses of emerging contaminants, metals, and greenhouse gas abatement with constructed wetlands should be documented for water quality protection in agricultural settings. Lastly, cost-benefit analyses are necessary to assess the feasibility and potential promotion through incentive programs, geographic locations, and regional NPS goals for using these systems in agricultural systems and need to be further explored in future studies.

\section{ACKNOWLEDGEMENTS}

This project is based on research that was partially supported by the Nebraska Agricultural Experiment Station with funding from the Hatch capacity funding program (Accession No. 1014685), Hatch multistate capacity funding (Grant No. W-4045), the Great Lakes Restoration Initiative, and the USDA National Institute of Food and Agriculture. 


\section{REFERENCES}

Acreman, M., \& Holden, J. (2013). How wetlands affect floods. Wetlands, 33(5), 773-786. https://doi.org/10.1007/s13157-0130473-2

Ahmed, N., \& Thompson, S. (2019). The blue dimensions of aquaculture: A global synthesis. Sci. Total Environ., 652, 851861. https://doi.org/10.1016/j.scitotenv.2018.10.163

Bass, K. (2000). Evaluation of a small in-stream constructed wetland in North Carolina's coastal plain. Raleigh, NC: North Carolina State University.

Bayo, J., Gómez-López, M. D., Faz, A., \& Caballero, A. (2012). Environmental assessment of pig slurry management after local characterization and normalization. J. Cleaner Prod., 32, 227235. https://doi.org/10.1016/j.jclepro.2012.04.003

Beeson, R. C., \& Knox, G. W. (1991). Analysis of efficiency of overhead irrigation in container production. HortSci., 26(7), 848-850. https://doi.org/10.21273/hortsci.26.7.848

Beutel, M. W., Morgan, M. R., Erlenmeyer, J. J., \& Brouillard, E. S. (2014). Phosphorus removal in a surface-flow constructed wetland treating agricultural runoff. J. Environ. Qual., 43(3), 1071-1080. https://doi.org/10.2134/jeq2013.11.0463

Blankenberg, A. B., Paruch, A. M., Paruch, L., Deelstra, J., \& Haarstad, K. (2016). Nutrients tracking and removal in constructed wetlands treating catchment runoff in Norway. In J. Vymazal (Ed.), Natural and constructed wetlands (pp. 23-40). Cham, Switzerland: Springer. https://doi.org/10.1007/978-3319-38927-1_2

BLS. (2019). Price index: December 2019. USDL-20-0044. Washington, DC: U.S. Bureau of Labor Statistics.

Borin, M., \& Tocchetto, D. (2007). Five-year water and nitrogen balance for a constructed surface-flow wetland treating agricultural drainage waters. Sci. Total Environ., 380(1), 38-47. https://doi.org/10.1016/j.scitotenv.2006.12.039

Borin, M., Politeo, M., \& De Stefani, G. (2013). Performance of a hybrid constructed wetland treating piggery wastewater. Ecol. Eng., 51, 229-236. https://doi.org/10.1016/j.ecoleng.2012.12.064

Braskerud, B. C. (2002). Factors affecting phosphorus retention in small constructed wetlands treating agricultural nonpoint-source pollution. Ecol. Eng., 19(1), 41-61. https://doi.org/10.1016/S0925-8574(02)00014-9

Burchell II, M. R., Skaggs, R. W., Lee, C. R., Broome, S., Chescheir, G. M., \& Osborne, J. (2007). Substrate organic matter to improve nitrate removal in surface-flow constructed wetlands. J. Environ. Qual., 36(1), 194-207. https://doi.org/10.2134/jeq2006.0022

Buric, M., Bláhovec, J., \& Kouril, J. (2015). Back to the roots: The integration of a constructed wetland into a recirculating hatchery: A case study. PLoS One, 10(4), e0123577. https://doi.org/10.1371/journal.pone.0123577

Castelle, A. J., Johnson, A. W., \& Conolly, C. (1994). Wetland and stream buffer size requirements: A review. J. Environ. Qual., 23(5), 878-882. https://doi.org/10.2134/jeq1994.00472425002300050004x

Chen, D., Gu, X., Zhu, W., He, S., Wu, F., Huang, J., \& Zhou, W. (2019). Denitrification- and anammox-dominant simultaneous nitrification, anammox, and denitrification (SNAD) process in subsurface-flow constructed wetlands. Bioresour. Tech., 271, 298-305. https://doi.org/10.1016/j.biortech.2018.09.123

Chen, H., Ivanoff, D., \& Pietro, K. (2015). Long-term phosphorus removal in the Everglades stormwater treatment areas of south Florida in the United States. Ecol. Eng., 79, 158-168. https://doi.org/10.1016/j.ecoleng.2014.12.012

Christianson, L., Tyndall, J., \& Helmers, M. (2013). Financial comparison of seven nitrate reduction strategies for Midwestern agricultural drainage. Water Resour. Econ., 2-3, 30-56. https://doi.org/10.1016/j.wre.2013.09.001
Crumpton, W. G., \& Stenback, B. (2018). Annual report on performance of Iowa CREP wetlands: Monitoring and evaluation of wetland performance. Des Moines, IA: Iowa Department of Agriculture and Land Stewardship.

Crumpton, W. G., Stenback, G., Miller, B. A., \& Helmers, M. J. (2006). Potential benefits of wetland filters for tile drainage systems: Impact on nitrate loads to Mississippi River subbasins. CSREES project completion report. Washington, DC: USDA.

Dahl, T. (2000). Status and trends of wetlands in the conterminous United States 1986 to 1997. Washington, DC: U.S. Fish and Wildlife Service.

de la Varga, D., Diaz, M. A., Ruiz, I., \& Soto, M. (2013). Avoiding clogging in constructed wetlands by using anaerobic digesters as pre-treatment. Ecol. Eng., 52, 262-269. https://doi.org/10.1016/j.ecoleng.2012.11.005

Diaz, F. J., Ogeen, A. T., \& Dahlgren, R. A. (2012). Agricultural pollutant removal by constructed wetlands: Implications for water management and design. Agric. Water Mgmt., 104, 171183. https://doi.org/10.1016/j.agwat.2011.12.012

Dunne, E. J., Coveney, M. F., Hoge, V. R., Conrow, R., Naleway, R., Lowe, E. F., ... Wang, Y. (2015). Phosphorus removal performance of a large-scale constructed treatment wetland receiving eutrophic lake water. Ecol. Eng., 79, 132-142. https://doi.org/10.1016/j.ecoleng.2015.02.003

Euliss, N. H., Gleason, R. A., Olness, A., McDougal, R. L., Murkin, H. R., Robarts, R. D., ... Warner, B. G. (2006). North American prairie wetlands are important nonforested land-based carbon storage sites. Sci. Total Environ., 361(1), 179-188. https://doi.org/10.1016/j.scitotenv.2005.06.007

Fink, D. F., \& Mitsch, W. J. (2004). Seasonal and storm event during nutrient removal by a created wetland in an agricultural watershed. Ecol. Eng., 23(4-5), 313-325. https://doi.org/10.1016/j.ecoleng.2004.11.004

Finlayson, M., Chick, A., von Oertzen, I., \& Mitchell, D. (1987). Treatment of piggery effluent by an aquatic plant fiber. Biol. Wastes, 19(3), 179-196. https://doi.org/10.1016/02697483(87)90051-6

Gachango, F. G., Pedersen, S. M., \& Kjaergaard, C. (2015). Costeffectiveness analysis of surface-flow constructed wetlands (SFCW) for nutrient reduction in drainage discharge from agricultural fields in Denmark. Environ. Mgmt., 56(6), 14781486. https://doi.org/10.1007/s00267-015-0585-y

Gagnon, V., Maltais-Landry, G., Puigagut, J., Chazarenc, F., \& Brisson, J. (2010). Treatment of hydroponics wastewater using constructed wetlands in winter conditions. Water Air Soil Pollut., 212(1), 483-490. https://doi.org/10.1007/s11270-0100362-8

Goddard, G. L., \& Elder, J. F. (1997). Retention of sediments and nutrients in Jackson Creek wetland near Delavan Lake, Wisconsin, 1993-1995. USGS Water-Resources Investigations Report. Reston, VA: U.S. Geological Survey. https://doi.org/10.3133/wri974014

González, F. T., Vallejos, G. G., Silveira, J. H., Franco, C. Q., Garcia, J., \& Puigagut, J. (2009). Treatment of swine wastewater with subsurface-flow constructed wetlands in Yucatán, Mexico: Influence of plant species and contact time. Water SA, 35(3). https://doi.org/10.4314/wsa.v35i3.76778

Gorito, A. M., Ribeiro, A. R., Gomes, C. R., Almeida, C. M., \& Silva, A. M. (2018). Constructed wetland microcosms for the removal of organic micropollutants from freshwater aquaculture effluents. Sci. Total Environ., 644, 1171-1180.

https://doi.org/10.1016/j.scitotenv.2018.06.371

$\mathrm{Gu}$, B. (2008). Phosphorus removal in small constructed wetlands dominated by submersed aquatic vegetation in south Florida, USA. J. Plant Ecol., 1(1), 67-74.

https://doi.org/10.1093/jpe/rtm002 
Hammer, D. A. (Ed.). (1989). Constructed wetlands for wastewater treatment: Municipal, industrial and agricultural. Boca Raton. FL: CRC Press.

Han, J., Meng, X., Zhou, X., Yi, B., Liu, M., \& Xiang, W.-N. (2017). A long-term analysis of urbanization process, landscape change, and carbon sources and sinks: A case study in China's Yangtze River Delta region. J. Cleaner Prod., 141, 1040-1050. https://doi.org/https://doi.org/10.1016/j.jclepro.2016.09.177

Hansen, L. R., Hellerstein, D., Ribaudo, M., Williamson, J., Nulph, D., Loesch, C., \& Crumpton, W. (2015). Targeting investment to cost-effectively restore and protect wetland ecosystems: Some economic insights. In (N. E. Santiago, Ed.) Wetlands: Overview and targeted investment for restoration and protection (pp. 35107). Hauppauge, NY: Nova Science Publishers.

Harrington, C., Scholz, M., Culleton, N., \& Lawlor, P. G. (2012). The use of integrated constructed wetlands (ICW) for the treatment of separated swine wastewaters. Hydrobiologia, 692(1), 111-119. https://doi.org/10.1007/s10750-011-0945-4

Haverstock, M. J., Madani, A., Baldé, H., VanderZaag, A. C., \& Gordon, R. J. (2017). Performance of an agricultural wetlandreservoir-irrigation management system. Water, 9(7), 472. https://doi.org/10.3390/w9070472

Hayes, D. F., Olin, T. J., Fischenich, C. C., \& Palermo, M. (2000). Wetlands engineering handbook. Vicksburg, MS: U.S. Army Corps of Engineers.

Hefting, M. M., Clement, J.-C., Bienkowski, P., Dowrick, D., Guenat, C., Butturini, A., ... Verhoeven, J. T. (2005). The role of vegetation and litter in the nitrogen dynamics of riparian buffer zones in Europe. Ecol. Eng., 24(5), 465-482.

https://doi.org/10.1016/j.ecoleng.2005.01.003

Hoagland, C. R., Gentry, L. E., David, M. B., \& Kovacic, D. A. (2001). Plant nutrient uptake and biomass accumulation in a constructed wetland. J. Freshwater Ecol., 16(4), 527-540. https://doi.org/10.1080/02705060.2001.9663844

Hoffmann, C. C., Heiberg, L., Audet, J., Schonfeldt, B., Fuglsang, A., Kronvang, B., ... Jensen, H. S. (2012). Low phosphorus release but high nitrogen removal in two restored riparian wetlands inundated with agricultural drainage water. Ecol. Eng., 46, 75-87. https://doi.org/10.1016/j.ecoleng.2012.04.039

Humenik, F. J., Szogi, A. A., Hunt, P. G., Broome, S., \& Rice, M. (1999). Wastewater utilization: A place for managed wetlands. Asian-Asian-Australasian J. Animal Sci., 12(4), 629-632. https://doi.org/10.5713/ajas.1999.629

Hunt, P. G., Humenik, F. J., Szogi, A. A., Rice, J. M., Stone, K. C., Cutts, T. T., \& Edwards, J. P. (1993). Constructed wetland treatment of swine wastewater. ASAE Paper No. 932616. St. Joseph, MI: ASAE.

Iovanna, R., Hyberg, S., \& Crumpton, W. (2008). Treatment wetlands: Cost-effective practice for intercepting nitrate before it reaches and adversely impacts surface waters. J. Soil Water Cons., 63(1), 14A-15A. https://doi.org/10.2489/jswc.63.1.14A

Jager, D. F., Wilmking, M., \& Kukkonen, J. V. (2009). The influence of summer seasonal extremes on dissolved organic carbon export from a boreal peatland catchment: Evidence from one dry and one wet growing season. Sci. Total Environ., 407(4), 1373-1382. https://doi.org/10.1016/j.scitotenv.2008.10.005

Jamieson, T. S., Stratton, G. W., Gordon, R., \& Madani, A. (2003). The use of aeration to enhance ammonia nitrogen removal in constructed wetlands. Canadian Biosyst. Eng., 45(3), 9-14.

Jørgensen, C. J., \& Elberling, B. (2012). Effects of floodinginduced $\mathrm{N}_{2} \mathrm{O}$ production, consumption, and emission dynamics on the annual $\mathrm{N}_{2} \mathrm{O}$ emission budget in wetland soil. Soil Biol. Biochem., 53, 9-17. https://doi.org/10.1016/j.soilbio.2012.05.005

Juston, J., \& DeBusk, T. A. (2006). Phosphorus mass load and outflow concentration relationships in stormwater treatment areas for Everglades restoration. Ecol. Eng., 26(3), 206-223. https://doi.org/10.1016/j.ecoleng.2005.09.011

Kadlec, R. H., \& Knight, R. L. (1996). Treatment wetlands. New York, NY: Lewis Publishers.

Kadlec, R. H., \& Wallace, S. (2009). Treatment wetlands (2nd Ed.). Boca Raton, FL: CRC Press. https://doi.org/10.1201/9781420012514

Kadlec, R. H., Tanner, C. C., Hally, V. M., \& Gibbs, M. M. (2005). Nitrogen spiraling in subsurface-flow constructed wetlands: Implications for treatment response. Ecol. Eng., 25(4), 365-381. https://doi.org/10.1016/j.ecoleng.2005.06.009

Kasak, K., Kill, K., Pärn, J., \& Mander, U. (2018). Efficiency of a newly established in-stream constructed wetland treating diffuse agricultural pollution. Ecol. Eng., 119, 1-7. https://doi.org/10.1016/j.ecoleng.2018.05.015

Kim, H. C., Yoon, C. G., Son, Y. K., Rhee, H. P., \& Lee, S. B. (2010). Effects of open water on the performance of a constructed wetland for nonpoint-source pollution control. Water Sci. Tech., 62(5), 1003-1012. https://doi.org/10.2166/wst.2010.333

Knight, R. L., Payne, V. W., Borer, R. E., Clarke, R. A., \& Pries, J. H. (2000). Constructed wetlands for livestock wastewater management. Ecol. Eng., 15(1), 41-55. https://doi.org/10.1016/S0925-8574(99)00034-8

Knowles, R. (1982). Denitrification. Microbiol. Rev., 46(1), 43-70. https://doi.org/10.1128/MR.46.1.43-70.1982

Konnerup, D., Trang, N. T. D., \& Brix, H. (2011). Treatment of fishpond water by recirculating horizontal and vertical flow constructed wetlands in the tropics. Aquaculture, 313(1-4), 5764. https://doi.org/10.1016/j.aquaculture.2010.12.026

Koskiaho, J., Ekholm, P., Räty, M., Riihimäki, J., \& Puustinen, M. (2003). Retaining agricultural nutrients in constructed wetlands: Experiences under boreal conditions. Ecol. Eng., 20(1), 89-103. https://doi.org/10.1016/S0925-8574(03)00006-5

Kovacic, D. A., David, M. B., Gentry, L. E., Starks, K. M., \& Cooke, R. A. (2000). Effectiveness of constructed wetlands in reducing nitrogen and phosphorus export from agricultural tile drainage. J. Environ. Qual,, 29(4), 1262-1274. https://doi.org/10.2134/jeq2000.00472425002900040033x

Kovacic, D. A., Twait, R. M., Wallace, M. P., \& Bowling, J. M. (2006). Use of created wetlands to improve water quality in the Midwest: Lake Bloomington case study. Ecol. Eng., 28(3), 258270. https://doi.org/10.1016/j.ecoleng.2006.08.002

Larson, A. C., Gentry, L. E., David, M. B., Cooke, R. A., \& Kovacic, D. A. (2000). The role of seepage in constructed wetlands receiving agricultural tile drainage. Ecol. Eng., 15(1), 91-104. https://doi.org/10.1016/S0925-8574(99)00037-3

Lavrnić, S., Braschi, I., Anconelli, S., Blasioli, S., Solimando, D., Mannini, P., \& Toscano, A. (2018). Long-term monitoring of a surface-flow constructed wetland treating agricultural drainage water in northern Italy. Water, 10(5), 644. https://doi.org/10.3390/w10050644

Lee, C.-Y., Lee, C.-C., Lee, F.-Y., Tseng, S.-K., \& Liao, C.-J. (2004). Performance of subsurface-flow constructed wetland taking pretreated swine effluent under heavy loads. Bioresour. Tech., 92(2), 173-179. https://doi.org/10.1016/j.biortech.2003.08.012

Lee, S., Maniquiz, M. C., \& Kim, L.-H. (2010). Characteristics of contaminants in water and sediment of a constructed wetland treating piggery wastewater effluent. J. Environ. Sci., 22(6), 940-945. https://doi.org/10.1016/S1001-0742(09)60202-3

Lentz, A. H., Ando, A. W., \& Brozović, N. (2014). Water quality trading with lumpy investments, credit stacking, and ancillary benefits. JAWRA, 50(1), 83-100. https://doi.org/10.1111/jawr.12117 
Li, H., \& Tao, W. (2017). Efficient ammonia removal in recirculating vertical-flow constructed wetlands:

Complementary roles of anammox and denitrification in simultaneous nitritation, anammox, and denitrification process. Chem. Eng. J., 317, 972-979.

https://doi.org/10.1016/j.cej.2017.02.143

Li, M., Sun, L., \& Song, X. (2019). Adding maize cobs to vertical subsurface-flow constructed wetlands treating marine recirculating aquaculture system effluents: Carbon releasing kinetics and intensified nitrogen removal. Bioresour. Tech., 274, 267-271. https://doi.org/10.1016/j.biortech.2018.09.054

Liikanen, A., Puustinen, M., Koskiaho, J., Vaisanen, T., Martikainen, P., \& Hartikainen, H. (2004). Phosphorus removal in a wetland constructed on former arable land. J. Environ. Qual., 33(3), 1124-1132. https://doi.org/10.2134/jeq2004.1124

Lin, Y.-F., Jing, S.-R., Lee, D.-Y., \& Wang, T.-W. (2002). Nutrient removal from aquaculture wastewater using a constructed wetlands system. Aquaculture, 209(1), 169-184. https://doi.org/10.1016/S0044-8486(01)00801-8

Lin, Y.-F., Jing, S.-R., Lee, D.-Y., Chang, Y.-F., \& Sui, H.-Y. (2010). Constructed wetlands for water pollution management of aquaculture farms conducting earthen pond culture. Water Environ. Res., 82(8), 759-768. https://doi.org/10.2175/106143010X12609736966685

Lin, Y.-F., Jing, S.-R., Lee, D.-Y., Chang, Y.-F., Chen, Y.-M., \& Shih, K.-C. (2005). Performance of a constructed wetland treating intensive shrimp aquaculture wastewater under high hydraulic loading rate. Environ. Pollut., 134(3), 411-421. https://doi.org/10.1016/j.envpol.2004.09.015

Liu, W., Su, Y., Yang, R., Wang, X., \& Yang, X. (2010). Land use effects on soil organic carbon, nitrogen, and salinity in salinealkaline wetland. Sci. Cold Arid Regions, 2(3), 263-270.

Loehr, R. C. (1972). Agricultural runoff: Characteristics and control. J. Sanitary Eng. Div., 98(6), 909-925.

Lu, J., Fu, Z., \& Yin, Z. (2008). Performance of a water hyacinth (Eichhornia crassipes) system in the treatment of wastewater from a duck farm and the effects of using water hyacinth as duck feed. J. Environ. Sci., 20(5), 513-519. https://doi.org/10.1016/S1001-0742(08)62088-4

Lu, S. Y., Wu, F. C., Lu, Y. F., Xiang, C. S., Zhang, P. Y., \& Jin, C. X. (2009). Phosphorus removal from agricultural runoff by constructed wetland. Ecol. Eng., 35(3), 402-409. https://doi.org/10.1016/j.ecoleng.2008.10.002

Ludwig, A. L. (2010). Constructed floodplain wetland effectiveness for stormwater management. Blacksburg, VA: Virginia Tech.

Luo, P., Liu, F., Liu, X., Wu, X., Yao, R., Chen, L., ... Wu, J. (2017). Phosphorus removal from lagoon-pretreated swine wastewater by pilot-scale surface-flow constructed wetlands planted with Myriophyllum aquaticum. Sci. Total Environ., 576, 490-497. https://doi.org/10.1016/j.scitotenv.2016.10.094

Maniquiz, M. C., Choi, J. Y., Lee, S. Y., Kang, C. G., Yi, G. S., \& Kim, L. H. (2012). System design and treatment efficiency of a surface-flow constructed wetland receiving runoff impacted stream water. Water Sci. Tech., 65(3), 525-532. https://doi.org/10.2166/wst.2012.869

Mankin, K. R., \& Ikenberry, C. D. (2004). Batch reactor unvegetated wetland performance in treating dairy wastewater. JAWRA, 40(6), 1527-1535. https://doi.org/10.1111/j.17521688.2004.tb01603.x

Masi, F., Rizzo, A., Martinuzzi, N., Wallace, S. D., Van Oirschot, D., Salazzari, P., ... Bresciani, R. (2017). Upflow anaerobic sludge blanket and aerated constructed wetlands for swine wastewater treatment: A pilot study. Water Sci. Tech., 76(1), 6878. https://doi.org/10.2166/wst.2017.180

Maxwell, E., Peterson, E. W., \& O’Reilly, C. M. (2017). Enhanced nitrate reduction within a constructed wetland system: Nitrate removal within groundwater flow. Wetlands, 37(3), 413-422. https://doi.org/10.1007/s13157-017-0877-5

McMaine, J. T., Vogel, J. R., Belden, J. B., Schnelle, M. A., Morrison, S. A., \& Brown, G. O. (2020). Field studies of pollutant removal from nursery and greenhouse runoff by constructed wetlands. J. Environ. Qual., 49(1), 106-118. https://doi.org/10.1002/jeq2.20024

Meers, E., Rousseau, D. P., Blomme, N., Lesage, E., Du Laing, G., Tack, F. M., \& Verloo, M. G. (2005). Tertiary treatment of the liquid fraction of pig manure with Phragmites australis. Water Air Soil Pollut., 160(1), 15-26. https://doi.org/10.1007/s11270005-3428-2

Mercado-Borrayo, B. M., Cram Heydrich, S., Rosas Pérez, I., Hernández Quiroz, M., \& Ponce De León Hill, C. (2015). Organophosphorus and organochlorine pesticides bioaccumulation by Eichhornia crassipes in irrigation canals in an urban agricultural system. Intl. J. Phytoremed., 17(7), 701708. https://doi.org/10.1080/15226514.2014.964841

Messer, T. L., Burchell, M. R., Birgand, F., Broome, S. W., \& Chescheir, G. (2017a). Nitrate removal potential of restored wetlands loaded with agricultural drainage water: A mesocosmscale experimental approach. Ecol. Eng., 106, 541-554. https://doi.org/10.1016/j.ecoleng.2017.06.022

Messer, T. L., Burchell, M. R., Bohlke, J. K., \& Tobias, C. R. (2017b). Tracking the fate of nitrate through pulse-flow wetlands: A mesocosm-scale ${ }^{15} \mathrm{~N}$ enrichment tracer study. Ecol. Eng., 106, 597-608. https://doi.org/10.1016/j.ecoleng.2017.06.016

Miller, P. S., Mitchell, J. K., Cooke, R. A., \& Engel, B. A. (2002). A wetland to improve agricultural subsurface drainage water quality. Trans. ASAE, 45(5), 1305-1317. https://doi.org/10.13031/2013.11068

Minitab. (2010). Minitab statistical software, ver. 17. State College, PA: Minitab, Inc. Retrieved from www.minitab.com

Mitsch, W. J., \& Gosselink, J. G. (2000). The value of wetlands: Importance of scale and landscape setting. Ecol. Econ., 35(1), 25-33. https://doi.org/10.1016/S0921-8009(00)00165-8

Mitsch, W. J., \& Gosselink, J. G. (2015). Wetlands (5th ed.). Hoboken, NJ: John Wiley \& Sons.

Moore, M. T., Cooper, C. M., Smith, S., Cullum, R. F., Knight, S. S., Locke, M. A., \& Bennett, E. R. (2007). Diazinon mitigation in constructed wetlands: Influence of vegetation. Water Air Soil Pollut., 184(1), 313-321. https://doi.org/10.1007/s11270-0079418-9

Moreira, V. R., LeBlanc, B. D., Achberger, E. C., Frederick, D. G., $\&$ Leonardi, C. (2010). Design and evaluation of a sequential biological treatment system for dairy parlor wastewater in southeastern Louisiana. Appl. Eng. Agric., 26(1), 125-136. https://doi.org/10.13031/2013.29469

Moreno-Mateos, D., Comín, F. A., Pedrocchi, C., \& Causapé, J. (2009). Effect of wetlands on water quality of an agricultural catchment in a semi-arid area under land use transformation. Wetlands, 29(4), 1104-1113. https://doi.org/10.1672/08-196.1

Moshiri, G. A. (Ed.). (1993). Constructed wetlands for water quality improvement. Boca Raton, FL: CRC Press.

Mustafa, A., \& Scholz, M. (2011). Characterization of microbial communities transforming and removing nitrogen in wetlands. Wetlands, 31(3), 583-592. https://doi.org/10.1007/s13157-0110175-6

Mustafa, A., Scholz, M., Harrington, R., \& Carroll, P. (2009). Long-term performance of a representative integrated constructed wetland treating farmyard runoff. Ecol. Econ., 35(5), 779-790. https://doi.org/10.1016/j.ecoleng.2008.12.008

Narváez, L., Cunill, C., Cáceres, R., \& Marfa, O. (2011). Design and monitoring of horizontal subsurface-flow constructed wetlands for treating nursery leachates. Bioresour. Tech., 
102(11), 6414-6420.

https://doi.org/10.1016/j.biortech.2011.03.044

Novotny, V. (1999). Diffuse pollution from agriculture: A worldwide outlook. Water Sci. Tech., 39(3), 1-13. https://doi.org/10.2166/wst.1999.0124

NRCS. (2013). Conservation practice standard: Constructed wetland. Washington, DC: USDA Natural Resources Conservation Service.

Pant, H. K., \& Reddy, K. R. (2003). Potential internal loading of phosphorus in a wetland constructed in agricultural land. Water Res., 37(5), 965-972. https://doi.org/10.1016/S00431354(02)00474-8

Park, J. B. K., Craggs, R. J., \& Sukias, J. P. S. (2008). Treatment of hydroponic wastewater by denitrification filters using plant prunings as the organic carbon source. Bioresour. Tech., 99(8), 2711-2716. https://doi.org/10.1016/j.biortech.2007.07.009

Park, J. B. K., Craggs, R. J., \& Sukias, J. P. S. (2009). Removal of nitrate and phosphorus from hydroponic wastewater using a hybrid denitrification filter (HDF). Bioresour. Tech., 100(13), 3175-3179. https://doi.org/10.1016/j.biortech.2009.01.036

Park, J.-H., Kim, S.-H., Delaune, R. D., Cho, J.-S., Heo, J.-S., Ok, Y. S., \& Seo, D.-C. (2015). Enhancement of nitrate removal in constructed wetlands utilizing a combined autotrophic and heterotrophic denitrification technology for treating hydroponic wastewater containing high nitrate and low organic carbon concentrations. Agric. Water Mgmt., 162, 1-14.

https://doi.org/10.1016/j.agwat.2015.08.001

Pelissari, C., Guivernau, M., Vinas, M., Garcia, J., Velasco-Galilea, M., Souza, S. S., ... Avila, C. (2018). Effects of partially saturated conditions on the metabolically active microbiome and on nitrogen removal in vertical subsurface-flow constructed wetlands. Water Res., 141, 185-195.

https://doi.org/10.1016/j.watres.2018.05.002

Peterson, H. G. (1998). Use of constructed wetlands to process agricultural wastewater. Canadian J. Plant. Sci., 78(2), 199-210. https://doi.org/10.4141/p97-142

Pietro, K., \& Ivanoff, D. (2015). Comparison of long-term phosphorus removal performance of two large-scale constructed wetlands in south Florida, USA. Ecol. Eng., 79, 143-157. https://doi.org/10.1016/j.ecoleng.2014.12.013

Poach, M. E., Hunt, P. G., Reddy, G. B., Stone, K. C., Johnson, M. H., \& Grubbs, A. (2004). Swine wastewater treatment by marshpond-marsh constructed wetlands under varying nitrogen loads. Ecol. Eng., 23(3), 165-175. https://doi.org/10.1016/j.ecoleng.2004.09.001

Poach, M. E., Hunt, P. G., Reddy, G. B., Stone, K. C., Johnson, M. H., \& Grubbs, A. (2007). Effect of intermittent drainage on swine wastewater treatment by marsh-pond-marsh constructed wetlands. Ecol. Eng., 30(1), 43-50. https://doi.org/10.1016/j.ecoleng.2007.01.003

Poach, M. E., Hunt, P. G., Vanotti, M. B., Stone, K. C., Matheny, T. A., Johnson, M. H., \& Sadler, E. J. (2003). Improved nitrogen treatment by constructed wetlands receiving partially nitrified liquid swine manure. Ecol. Eng., 20(2), 183-197. https://doi.org/10.1016/S0925-8574(03)00024-7

Poe, A. C., Piehler, M. F., Thompson, S. P., \& Paerl, H. W. (2003). Denitrification in a constructed wetland receiving agricultural runoff. Wetlands, 23(4), 817-826. https://doi.org/10.1672/02775212(2003)023[0817:DIACWR]2.0.CO;2

Rahman, M. M., Roberts, K. L., Grace, M. R., Kessler, A. J., \& Cook, P. L. M. (2019). Role of organic carbon, nitrate, and ferrous iron on the partitioning between denitrification and DNRA in constructed stormwater urban wetlands. Sci. Total Environ., 666, 608-617.

https://doi.org/https://doi.org/10.1016/j.scitotenv.2019.02.225
Reinhardt, M., Gachter, R., Wehrli, B., \& Müller, B. (2005). Phosphorus retention in small constructed wetlands treating agricultural drainage water. J. Environ. Qual., 34(4), 1251-1259. https://doi.org/10.2134/jeq2004.0325

Roley, S. S., Tank, J. L., Tyndall, J. C., \& Witter, J. D. (2016). How cost-effective are cover crops, wetlands, and two-stage ditches for nitrogen removal in the Mississippi River basin? Water Resour. Econ., 15, 43-56. https://doi.org/10.1016/j.wre.2016.06.003

Rust, C. M., Aelion, C. M., \& Flora, J. R. (2000). Control of pH during denitrification in subsurface sediment microcosms using encapsulated phosphate buffer. Water Res., 34(5), 1447-1454. https://doi.org/10.1016/S0043-1354(99)00287-0

Saeed, T., \& Sun, G. (2012). A review on nitrogen and organics removal mechanisms in subsurface-flow constructed wetlands: Dependency on environmental parameters, operating conditions, and supporting media. J. Environ. Mgmt., 112, 429-448. https://doi.org/10.1016/j.jenvman.2012.08.011

Sano, D., Hodges, A., \& Degner, R. (2005). Economic analysis of water treatments for phosphorus removal in Florida. Gainesville, FL: University of Florida Institute of Food and Agricultural Science.

Schwartz, M. E., \& Boyd, C. E. (1995). Constructed wetlands for treatment of channel catfish pond effluents. The Progressive Fish-Culturist, 57(4), 255-266. https://doi.org/10.1577/15488640(1995)057<0255:CWFTOC >2.3.CO;2

Shpigel, M., Ben-Ezra, D., Shauli, L., Sagi, M., Ventura, Y., Samocha, T., \& Lee, J. J. (2013). Constructed wetland with Salicornia as a biofilter for mariculture effluents. Aquaculture, 412-413, 52-63. https://doi.org/10.1016/j.aquaculture.2013.06.038

Sim, C. H., Yusoff, M. K., Shutes, B., Ho, S. C., \& Mansor, M. (2008). Nutrient removal in a pilot- and full-scale constructed wetland, Putrajaya City, Malaysia. J. Environ. Mgmt., 88(2), 307-317. https://doi.org/10.1016/j.jenvman.2007.03.011

Søvik, A. K., \& Mørkved, P. T. (2008). Use of stable nitrogen isotope fractionation to estimate denitrification in small constructed wetlands treating agricultural runoff. Sci. Total Environ., 392(1), 157-165. https://doi.org/10.1016/j.scitotenv.2007.11.014

Spieles, D. J., \& Mitsch, W. J. (1999). The effects of season and hydrologic and chemical loading on nitrate retention in constructed wetlands: A comparison of low- and high-nutrient riverine systems. Ecol. Econ., 14(1), 77-91. https://doi.org/10.1016/S0925-8574(99)00021-X

Stone, K. C., Poach, M. E., Hunt, P. G., \& Reddy, G. B. (2004). Marsh-pond-marsh constructed wetland design analysis for swine lagoon wastewater treatment. Ecol. Econ., 23(2), 127-133. https://doi.org/10.1016/j.ecoleng.2004.07.008

Summerfelt, S. T., Adler, P. R., Glenn, D. M., \& Kretschmann, R. N. (1999). Aquaculture sludge removal and stabilization within created wetlands. Aquacult. Eng., 19(2), 81-92. https://doi.org/10.1016/S0144-8609(98)00042-9

Taylor, M. D., White, S. A., Chandler, S. L., Klaine, S. J., \& Whitwell, T. (2006). Nutrient management of nursery runoff water using constructed wetland systems. HortTech., 16(4), 610614. https://doi.org/10.21273/horttech.16.4.0610

Thoren, A., Legrand, C., \& Tonderski, K. S. (2004). Temporal export of nitrogen from a constructed wetland: Influence of hydrology and senescing submerged plants. Ecol. Econ., 23(4), 233-249. https://doi.org/10.1016/j.ecoleng.2004.09.007

Tilley, D. R., Badrinarayanan, H., Rosati, R., \& Son, J. (2002). Constructed wetlands as recirculation filters in large-scale shrimp aquaculture. Aquacult. Eng., 26(2), 81-109. https://doi.org/10.1016/S0144-8609(02)00010-9 
Tolomio, M., Dal Ferro, N., \& Borin, M. (2019). Multi-year N and $\mathrm{P}$ removal of a 10 -year-old surface-flow constructed wetland treating agricultural drainage waters. Agronomy, 9(4), 170. https://doi.org/10.3390/agronomy9040170

Tonderski, K. S., Arheimer, B., \& Pers, C. B. (2005). Modeling the impact of potential wetlands on phosphorus retention in a Swedish catchment. Ambio, 34(7), 544-551. https://doi.org/10.1579/0044-7447-34.7.544

Uggetti, E., Hughes-Riley, T., Morris, R. H., Newton, M. I., Trabi, C. L., Hawes, P., ... Garcia, J. (2016). Intermittent aeration to improve wastewater treatment efficiency in pilot-scale constructed wetland. Sci. Total Environ., 559, 212-217. https://doi.org/10.1016/j.scitotenv.2016.03.195

USACE. (1987). Wetland delineation manual. Vicksburg, MS: U.S. Army Corps of Engineers.

USDA-NRCS. (2019). Rate for federal water projects. Washington, DC: USDA Natural Resources Conservation Service.

USEPA. (2000). Guiding principles for constructed treatment wetlands: Providing for water quality and wildlife habita. Washington, DC: U.S. Environmental Protection Agency.

USEPA. (2004). Constructed treatment wetlands. Washington, DC: U.S. Environmental Protection Agency.

van Rijn, J. (1996). The potential for integrated biological treatment systems in recirculating fish culture: A review. Aquaculture, 139(3), 181-201. https://doi.org/10.1016/0044-8486(95)01151-X

van Rijn, J. (2013). Waste treatment in recirculating aquaculture systems. Aquacult. Eng., 53, 49-56. https://doi.org/10.1016/j.aquaeng.2012.11.010

van Rijn, J., Tal, Y., \& Schreier, H. J. (2006). Denitrification in recirculating systems: Theory and applications. Aquacult. Eng., 34(3), 364-376. https://doi.org/10.1016/j.aquaeng.2005.04.004

Vymazal, J. (2007). Removal of nutrients in various types of constructed wetlands. Sci. Total Environ., 380(1-3), 48-65. https://doi.org/10.1016/j.scitotenv.2006.09.014

Vymazal, J. (2009). The use constructed wetlands with horizontal subsurface flow for various types of wastewater. Ecol. Econ., 35(1), 1-17. https://doi.org/10.1016/j.ecoleng.2008.08.016

Walbridge, M. R., \& Lockaby, B. G. (1994). Effects of forest management on biogeochemical functions in southern forested wetlands. Wetlands, 14(1), 10-17. https://doi.org/10.1007/BF03160617

Webb, J. M., Quinta, R., Papadimitriou, S., Norman, L., Rigby, M., Thomas, D. N., \& Le Vay, L. (2013). The effect of halophyte planting density on the efficiency of constructed wetlands for the treatment of wastewater from marine aquaculture. Ecol. Econ., 61, 145-153. https://doi.org/10.1016/j.ecoleng.2013.09.058

White, S. A. (2017). Design and season influence nitrogen dynamics in two surface-flow constructed wetlands treating nursery irrigation runoff. Water, 10(1), 8. https://doi.org/10.3390/w10010008

White, S. A., Taylor, M. D., Chandler, S. L., Whitwell, T., \& Klaine, S. J. (2010). Remediation of nitrogen and phosphorus from nursery runoff during the spring via free water surface constructed wetlands. J. Environ. Hort., 28(4), 209-217. https://doi.org/10.24266/0738-2898-28.4.209

Wilson, C., Albano, J., Mozdzen, M., \& Riiska, C. (2010). Irrigation water and nitrate-nitrogen loss characterization in southern Florida nurseries: Cumulative volumes, runoff rates, nitrate-nitrogen concentrations and loadings, and implications for management. HortTech., 20(2), 325-330. https://doi.org/10.21273/horttech.20.2.325

Wu, H., Zhang, J., Ngo, H. H., Guo, W., Hu, Z., Liang, S., ... Liu, H. (2015). A review on the sustainability of constructed wetlands for wastewater treatment: Design and operation. Bioresour. Tech., 175, 594-601. https://doi.org/10.1016/j.biortech.2014.10.068

Zachritz, W. H., Hanson, A. T., Sauceda, J. A., \& Fitzsimmons, K. M. (2008). Evaluation of submerged surface-flow (SSF) constructed wetlands for recirculating tilapia production systems. Aquacult. Eng., 39(1), 16-23. https://doi.org/10.1016/j.aquaeng.2008.05.001

Zedler, J. B. (2003). Wetlands at your service: Reducing impacts of agriculture at the watershed scale. Front. Ecol. Environ., 1(2), 65-72. https://doi.org/10.1890/15409295(2003)001[0065:WAYSRI]2.0.CO;2

Zedler, J. B., \& Kercher, S. (2005). Wetland resources: Status, trends, ecosystem services, and restorability. Ann. Rev. Environ. Resour., 30(1), 39-74. https://doi.org/10.1146/annurev.energy.30.050504.144248

Zhang, L., Xia, X., Zhao, Y., Xi, B., Yan, Y., Guo, X., ... Zhan, J. (2011). The ammonium nitrogen oxidation process in horizontal subsurface-flow constructed wetlands. Ecol. Econ., 37(11), 1614-1619. https://doi.org/10.1016/j.ecoleng.2011.06.020

Zhang, S. Y., Zhou, Q. H., Xu, D., He, F., Cheng, S. P., Liang, W., ... Wu, Z. B. (2010). Vertical-flow constructed wetlands applied in a recirculating aquaculture system for channel catfish culture: Effects on water quality and zooplankton. Polish J. Environ. Stud., 19(5), 1063-1070. 